\title{
Variable eruptive styles in an ancient monogenetic volcanic field: examples from the Permian Levín Volcanic Field (Krkonoše Piedmont Basin, Bohemian Massif)
}

\author{
Marcela STÁRKOVÁ ${ }^{*}$, Vladislav RAPPRICH ${ }^{1}$, Christoph BREITKREUZ² \\ ${ }^{1}$ Czech Geological Survey, Klárov 3, 11821 Prague 1, Czech Republic; marcela.starkova@geology.cz \\ ${ }^{2}$ Institut für Geologie, TU Bergakademie Freiberg, Bernhard von Cotta Str. 2, 09599 Freiberg, Germany \\ * Corresponding author
}

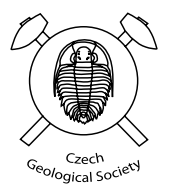

\begin{abstract}
The Permian pyroclastic deposits of the Levín Volcanic Field within the Krkonoše Piedmont Basin were studied in terms of volcanology. Pyroclastic rocks are exposed in two quarries and the study was supported with a $30 \mathrm{~m}$ deep borehole K1 penetrating these rocks. The pyroclastic rocks are altered but preserved textures enable reconstruction of eruptive styles. The volcanic sequence exposed in the abandoned Hvězda quarry starts with a phreato-Strombolian pyroclastic rocks rich in basaltic scoria, cuspate glass shards, armoured- and accretionary lapilli overlain with mafic lava. Subsequent activity was phreatomagmatic in style and produced fall-out of accretionary lapilli and accumulation of base surge deposits. Overlying subhorizontally bedded matrix-supported pyroclastic deposits are rich in scoria and contain spindle-shaped bombs. These rocks are interpreted as mafic pyroclastic flow deposits related to Strombolian eruptions. A similar succession capped by scoriaceous fall-out deposit was documented in the K1 borehole. A coherent mafic volcanic rock (lava or sill) terminates the succession exposed in the Hvězda quarry.

Agglutinates at the base of the Studenec quarry were produced during Hawaiian eruptions building up a spatter cone. The cone most probably dammed a stream and created an ephemeral lake. Increasing influence of water on eruptive styles is documented in overlying pyroclastic deposits of phreatomagmatic eruptions. Subsequent lava flowed into the lake. Quenching of the lava resulted in formation of pillows enclosed in hyaloclastite breccia. Further up in the exposure, transition of pillow to massive lava has been recognized. Overlaying pyroclastic deposits are matrix-supported and rich in scoria and spindle-shaped bombs. Similarly to the Hvězda quarry, these are interpreted as mafic pyroclastic flow deposits.

Volcanic activity in the Levín Volcanic Field was characterized by Hawaiian, Strombolian, phreato-Strombolian and phreatomagmatic eruptions accompanying lava effusions and possibly sills emplacement. The lavas were emitted in both subaerial and subaquatic conditions. The character and distribution of volcaniclastic facies suggests existence of several monogenetic volcanoes.
\end{abstract}

Keywords: Hawaiian eruption, Strombolian eruption, phreatomagmatic eruption, melaphyre, volcanic facies analysis, Czech Republic Received: 21 February 2011; accepted: 7 June 2011; handling editor: V. Kachlik

\section{Introduction}

Mafic intracontinental volcanism is usually expressed as volcanic fields with groups of monogenetic volcanoes; the latter originate from a single or a few eruptions of rapidly ascending, low-volume mafic magma batches (e.g., Sigurdsson 1999). The monogenetic volcanoes occur as scoria cones, tuff cones or rings, and maars, depending on eruptive style influenced by the eruption environment (Lorenz 2003; Valentine et al. 2005, 2006; Genareau et al. 2010; Kereszturi et al. 2011). Eruptive styles at monogenetic centres can be really complex if sufficient magma supply is combined with groundwater source (e.g., Konečný and Lexa 2003; Martin and Németh 2006; Carrasco-Núñez et al. 2009).

Most studies are focused on Holocene or Pleistocene monogenetic volcanic fields because of volcanic hazards in adjacent areas. For this reason, processes of magma ascent, degassing, phreatomagmatic interactions and crystallization in monogenetic volcanoes have been studied worldwide (Head and Wilson 1989; Valentine et al. 2005; Keating et al. 2007; Lorenz and Kurszlaukis 2007; Risso et al. 2008). However, the interior of active or very young volcanic cones can be seldom reached. Therefore, research on Quaternary monogenetic cones became combined with studies of Neogene scoria cones (e.g., Houghton and Schmincke 1989; Bednarz and Schmincke 1990; Awdankiewicz 2005; Rapprich et al. 2007). Structure of even older monogenetic volcanoes is being studied and interpreted much less frequently for several reasons. Volcaniclastic rocks are prone to alteration and weathering. The small cones built of unconsolidated pyroclastic deposits are subject to erosion and they are usually rapidly destroyed. The edifices 
of monogenetic volcanoes of Pre-Neogene age were preserved only if rapidly buried by other volcanic or sedimentary deposits. Environment with periods of rapid sedimentation is typical of post-collisional intermontane and foreland basins (e.g., Burbank and Johnson 1983). Such setting occurred in Central and NW Europe in Late Palaeozoic, after the Variscan Orogeny (Brookfield 1980; Schäfer 1989; Prouza and Tásler 2001; Martínek et al. 2006; Martínek and Štolfová 2009). Rapid burial by thick volcanosedimentary sequences preserved many volcanic landforms of Late Carboniferous to Permian age allowing their modern research (Geißler et al. 2008; Seghedi 2011). Papers dealing with volcanic systems in Central European Late Paleozoic basins focused mainly on silicic Halle Volcanic Complex (Romer et al. 2001; Breitkreuz and Mock 2004; Mock et al. 2005; Paulick and Breit- kreuz 2005; Breitkreuz et al. 2009) and a shield volcano under the city of Berlin (Hoth et al. 1993; Benek et al. 1996; Geißler et al. 2008). Bimodal volcanism (tholeiitic basalt to rhyolite) and its interactions with siliciclastic sedimentation and basin development were investigated in the Saar-Nahe Basin in western Germany (Stollhofen et al. 1999; Lorenz and Haneke 2004; Stollhofen and Stanistreet 2007).

Studies on monogenetic volcanism in intermontane or peripheral foreland basins of the Variscan Orogen in the Bohemian Massif are scarce. Several of them dealt with the petrology and geochemistry of volcanic rocks within the Intra-Sudetic Basin (Awdankiewicz 1999, 2004; Ulrych et al. 2006). Similarly, previous research on mafic volcanic rocks within the Krkonoše Piedmont Basin (KPB) was focused on petrology and general geochemi-

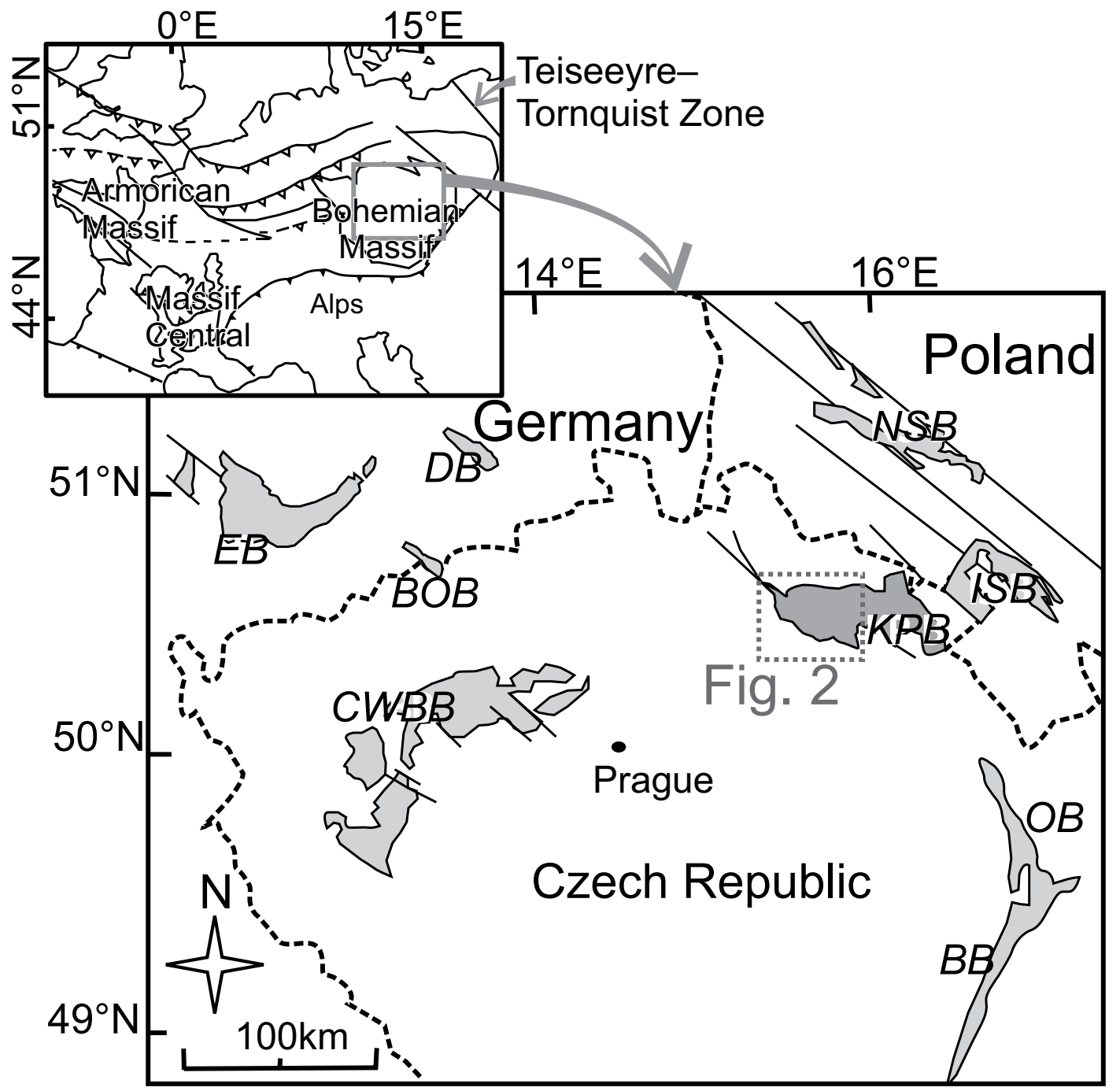

Fig. 1 Distribution of the Late Palaeozoic intermontane basins in the Bohemian Massif and its northern vicinity: BB - Boskovice Basin, BOB Brandov-Obersdorf Basin, CWBB - Central-Western Bohemia Basin, DB - Döhlen Basin, EB - Erzgebirge Basin, KPB - Krkonoše Piedmont Basin, ISB - Intra-Sudetic Basin, NSB - North-Sudetic Basin, OB - Orlice Basin (adapted after Pešek 2001). Location of the study area (Fig. 2) is also indicated. 
cal characteristics (Ponikelská 1982; Schovánková 1985, 1989; Ulrych et al. 2002, 2006) and rather little attention was paid to the emplacement processes of the volcanic rocks, eruptive styles and behaviour of these volcanoes. Presence of mafic volcaniclastic rocks in the KPB was first observed by Šreinová and Šrein (1997) but first notes on their genetic interpretation have been published somewhat later (Rapprich 2008a, b).

Our current research was focused on the products of mafic volcanism in the central part of the KPB, namely in the Levín Volcanic Field. The aim was to reconstruct volcanic processes in a monogenetic volcanic field situated in an intermontane basin, and to compare volcanic facies and textures preserved with modern volcanoes and their eruptive products. Among the mafic volcanic complexes known from the KPB, the Levín Volcanic Field sticks out for the quality of its exposures, its broad spectrum of pyroclastic deposits and the variability of ancient volcanic processes operating within a relatively small ancient monogenetic volcanic field.

\section{Geological setting}

\subsection{Krkonoše Piedmont Basin}

The collapse of the Variscan Orogen was associated with a significant phase of Permo-Carboniferous magmatism within the orogen and its foreland (NE German Basin, NW part of the Polish Basin, Oslo Rift, northern Spain and NW Bohemia: e.g., Timmerman 2008). A period of crustal instability and re-equilibration throughout Western and Central Europe was followed by transtensional/ extensional tectonic activity and rifting (Ziegler 1990; Krawczyk et al. 1999; Van Wees et al. 2000), when basins were formed within internide or externide positions of the Variscan Orogen.

In the Bohemian Massif was formed a SW-NE trending belt of intermontane basins, extending from Central Bohemia to as far as Sudetes (Poland - Fig. 1). This belt comprises the Central-Western Bohemian Basin, the Krkonoše Piedmont Basin and the Intra-Sudetic Basin (Pešek 2001). Sedimentation in the intermontane basins was sometimes accompanied by intense volcanic activity of two distinct magmatic suites: i) silicic volcanic rocks (rhyolites, rhyodacites, dacites and their pyroclastics including ignimbrites) produced by partial melting of the Earth's crust and ii) mafic volcanic rocks, so-called melaphyres (olivine basalts, basaltic andesites, andesites, trachybasalts, basaltic trachyandesites and their pyroclastics), derived from fairly metasomatized mantle (Ulrych et al. 2006).

The Krkonoše Piedmont Basin volcanosedimentary infill formed in the early post-orogenic phase, during
Westphalian, and developed till Saxonian times (Moscovian to Sakmarian, c. 310-280 Ma; Martínek et al. 2006). The continental succession of the KPB overlying crystalline basement rocks begins with Upper Carboniferous basal conglomerates, sandstones and breccias. The Red bed type of alluvial/lacustrine sedimentation with a few grey or variegated lacustrine layers continued during Permian (Martínek et al. 2006). The sedimentary infill of the KPB (with total thickness of $1800 \mathrm{~m}$ ) has been subdivided into eight formations (Prouza and Tásler 2001) with laterally variable thickness: 1 Kumburk Fm. (Asturian-Barruelian, maximal thickness of $600 \mathrm{~m}$ in southern part of the KPB), 2 Syřenov Fm. (Stephanian $\mathrm{B}$, maximal thickness of $120 \mathrm{~m}$ in southern part), $3 \mathrm{Se}$ mily Fm. (Stephanian C, maximal thickness of $500 \mathrm{~m}$ in central part), 4 Vrchlabi Fm. (lowermost Rotliegend Autunian, maximal thickness of $530 \mathrm{~m}$ in northern part), 5 Prosečné Fm. (lower Rotliegend $\sim$ Autunian maximal thickness of $400 \mathrm{~m}$ in central part), 6 Chotěvice Fm. (Rotliegend $\sim$ Autunian, erosional relic), 7 Trutnov Fm. (upper Rotliegend $\sim$ Saxonian) and 8 Bohuslavice Fm. (Zechstein $\sim$ Thuringian) but only the first six of them are preserved in the western part of the KPB, where the volcanic rocks occur (Figs 2 and 3).

Volcanic intercalations in the KPB include dacitic lavas in the Kumburk Fm., mafic volcanic rocks in the Vrchlabí and Prosečné formations, thin volcaniclastic layers (possibly distal ash-fall tuffs) in the Prosečné Fm. and rhyolitic ignimbrite in the Chotěvice Fm.

The mafic volcanic rocks are found as effusive (aphanitic or porphyritic lavas with "dry" mineral assemblage) as well as subvolcanic bodies (phaneritic rocks with biotite and/or amphibole). The high-level intrusive mafic rocks - dolerites and olivine dolerites - occur in two main bodies. The Tábor-Košt'álov intrusion is located in the western and the Strážník sill in the northern parts of the KPB (Fig. 2). The effusive mafic volcanic rocks are present in following units:

1. The Lomnice Volcanic Complex, which belongs to the upper part of the Vrchlabí Fm. with slight overlap to the lowermost Prosečné Fm. in western part of the KPB. The Lomnice Volcanic Complex consists of lavas associated with subordinate hyaloclastites. The thickness of individual lavas ranges in order of few metres and they are locally interbedded with siliciclastic sediments. The total thickness of the lava sequence reaches $c .40 \mathrm{~m}$.

2. Lavas at Těhník intercalated in sedimentary rocks of the Prosečné Fm.

3. The Levín Volcanic Field (LVF; c. $25 \mathrm{~km}^{2}$ ) in the central part of the KPB spanning the lowermost part of the Prosečné Fm. and possibly also top of the Vrchlabí Fm. It consists of thin mafic lavas alternating with pyroclastic deposits. 


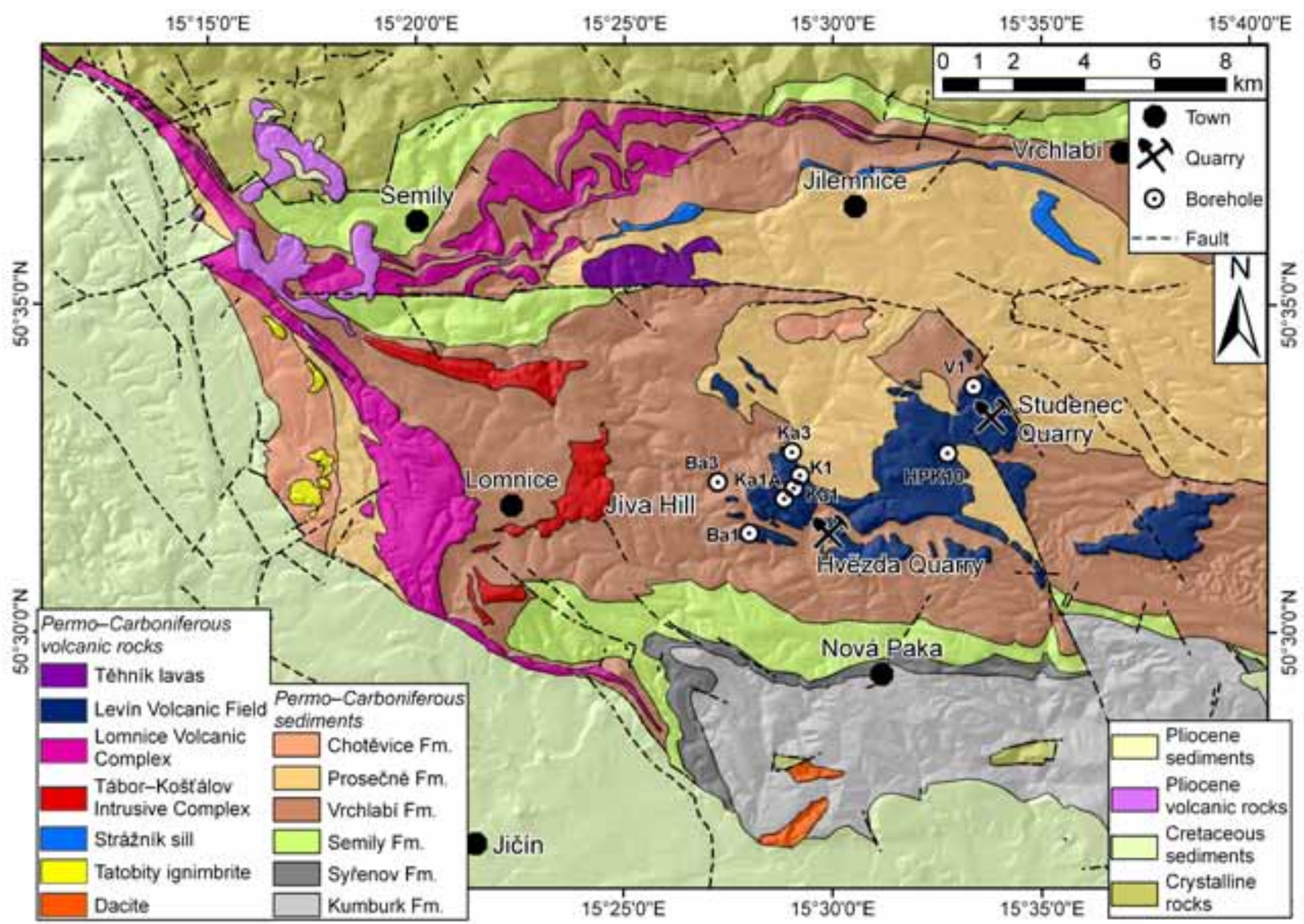

Fig. 2 Simplified geological map of the western part of the Krkonoše Piedmont Basin (based on the digital geological map 1:50 000 of the Czech Republic, http://www.geology.cz/extranet/geodata/mapserver, modified according to unpublished authors' observations).

\subsection{Levín Volcanic Field}

The Levín Volcanic Field is a name for a Permian volcanic area in the central part of the KPB introduced in this paper. However, the original volcanic cones cannot be distinguished in present morphology. On the other hand, distribution and character of volcanic rocks suggest a presence of several monogenetic volcanic centres. Based on the knowledge of the KPB stratigraphy, we assume the presence of some $800 \mathrm{~m}$ of basin fill below the Levín Volcanic Field. The strata forming the LVF lie sub-horizontally. The total thickness of the volcanic rocks reaches $60 \mathrm{~m}$. Data from boreholes (e.g., Ka1, V1 - Hošek et al. 1963; Bíža et al. 1982) combined with results of new geological mapping document the presence of at least five lava horizons with thickness varying between 2 and $20 \mathrm{~m}$. The thickness of volcaniclastic deposits penetrated by boreholes is up to $40 \mathrm{~m}$.

The composition of lavas within the LVF varies from olivine basalt to olivine-free basalt (or basaltic andesite). In previous works (e.g., Ponikelská 1982; Schovánková $1985,1989)$, the studied rocks were classified as "andesitoids" (andesitic rocks) but the silica content seems to be overestimated due to presence of agate mineralization in amygdales. Chemical composition of less altered lavas
$\left(\mathrm{SiO}_{2} 50-53\right.$ wt. \%, $\mathrm{TiO}_{2} 1.40-1.65$ wt. \%, $\mathrm{MgO} 4-6$ wt. \%, Cr 75-115 ppm, Ni 45-71 ppm and Zr 250-435 ppm after Schovánková 1989 and unpublished data of authors) leads to classification of these rocks as basalts and basaltic andesites to trachybasalts and basaltic trachyandesites as most of the samples plot on, or close to, the dividing lines between individual fields.

\section{Methods}

The picturesque landscape of the Levín Highland offers limited number of exposures but there are two quarries with excellent profiles available for studies. These quarries are situated on opposite margins of the LVF: the abandoned Hvězda quarry at the SW margin and the operating Studenec quarry in the NE (Fig. 2). Several other smaller outcrops of volcaniclastic deposits were studied in western and southeastern vicinities of the Hvězda quarry, at the southern margin of the LVF as well as in the N, close to the Studenec quarry. In addition a shallow borehole K1 was drilled near the Hvězda quarry (see below) in order to verify thickness and character of volcaniclastic rocks beneath outcropping lavas. 


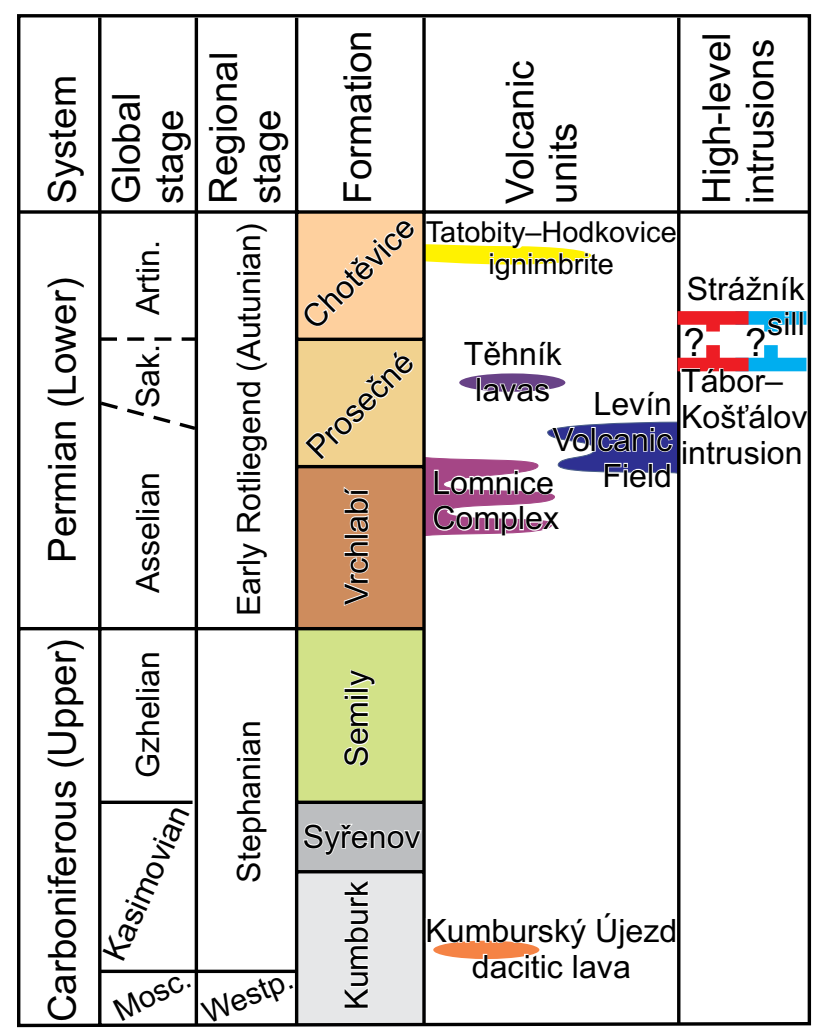

Fig. 3 Stratigraphic scheme of the volcanosedimentary infill of the western part of the Krkonoše Piedmont Basin (adapted after Martínek and Štolfová 2009). Artin. - Artinskian, Mosc. - Moscovian, Sak. Sakmarian, Westp. - Westphalian.

The extent and stratigraphic relations of described volcanic units were determined by geological mapping on scale 1:25000 (Stárková et al. 2010) supported by studies in one operating and one abandoned quarry. Surface-geological data were combined with existing borehole data (Ba-1, Ba-3, Ka1, Ka1A, Ka3, V-1, HPK-10 - Hošek et al. 1963; Skořepa 1978; Benda et al. 1981; Bíža et al. 1982). Moreover, a new borehole K1 was drilled by the SKB-4 machine with double core. It started with the $93 \mathrm{~mm}$ core diameter and after the first lithological change - it continued with the $76 \mathrm{~mm}$ diameter. The efficiency of the drilling was about $90 \%$ in solid rocks and the borehole reached a depth of $30 \mathrm{~m}$.

Grainsize, sorting, texture and structure of each defined volcanic unit were studied in the field on outcrops and on hand-specimens. Additionally, petrography of deposits and geometry with petrography of clasts present were studied under polarizing microscope. A secondary electron image of accretionary lapilli from the Hvězda quarry has been obtained on electron microscope CamScan CS 3200 at accelerating voltage $15 \mathrm{kV}$ in the microanalytical laboratory of the Czech Geological Survey in Prague.

\section{Results}

\subsection{Hvězda quarry $\left(50^{\circ} 31^{\prime} 38^{\prime \prime} N, 15^{\circ} 29^{\prime} 42^{\prime \prime} E\right)$}

Mafic lavas and mafic pyroclastic deposits alternate in the Hvězda quarry and surrounding area in the south-western LVF. Volcanic succession exposed in the Hvězda quarry, c. $12 \mathrm{~m}$ thick, consists of lower pyroclastic sequence (Hv1), lower lava flow (Hv2), upper pyroclastic sequence (Hv3) and upper lava (Hv4) (Figs 4 and 5).

The lowermost sequence Hv1 consists of six volcaniclastic units, named Hv1-A to Hv1-F. Hv1-A is a bedded mica-rich lapilli-tuff with an exposed thickness of 15 $\mathrm{cm}$; its base has not been reached. Macroscopically, the deposit appears to be dominated by a matrix enclosing $0.5-5 \mathrm{~cm}$ large fragments of chloritized vesicular glass (scoria). The matrix is rich in mica flakes (mostly muscovite) about 1-2 $\mathrm{mm}$ across. In microscope, fragments of chloritized scoria and glass shards can be identified. The scoria fragments are coated with brown volcanic ash forming armoured lapilli. Similarly, the ash coats also fragments of siltstones and quartz grains. The quartz grains, and also mica flakes, were most likely gathered by the eruption from underlying sandstones and arkoses. Even though the deposit macroscopically looks like matrix-supported, the ash particles in the groundmass are bond together to spherical aggregates. These ash aggregates (Scolamcchia et al. 2005) resemble structure of core-type accretionary lapilli (Schumacher and Schmincke 1991) but their diameter remains below the lapilli size. The individual ash aggregates are in touch and no more ash is present in between them. The fabric of Hv1-A is therefore clast-supported.

A discontinuous lens of matrix-supported scoriaceous lapilli-tuff with fragments of chloritized scoria (Hv1-B) is interbedded between the layers Hv1-A and Hv1-C. The scoria fragments are abundant but do not exceed $5 \mathrm{~mm}$. Maximum thickness of this lens reaches $5 \mathrm{~cm}$.

About $20 \mathrm{~cm}$ thick Hv1-C massive tuff with lenses of lapilli-tuff macroscopically mimics the matrix-supported fabric. In thin section the clast-supported texture is evident. It is poorer in mica flakes and fragments of chloritized scoria compared to underlying layers. The angular fragments with ragged outlines of scoria are concentrated in lenses and their size varies from 2 to 10 $\mathrm{mm}$. The scoria fragments are mostly coated with thin brown rim of hematitized ash (Fig. 6a-b) to the form of armoured lapilli. Only few scoria clasts are uncoated. The vesicles in scoria fragments are stretched and some scoria contain plagioclase phenocrysts and scarcely also glomerocrysts. Occasionally, a siltstone xenolith with strongly irregular shape is present in the core of armoured lapilli. The brown ash macroscopically mimics groundmass but in the microscope, it is obvious that the 


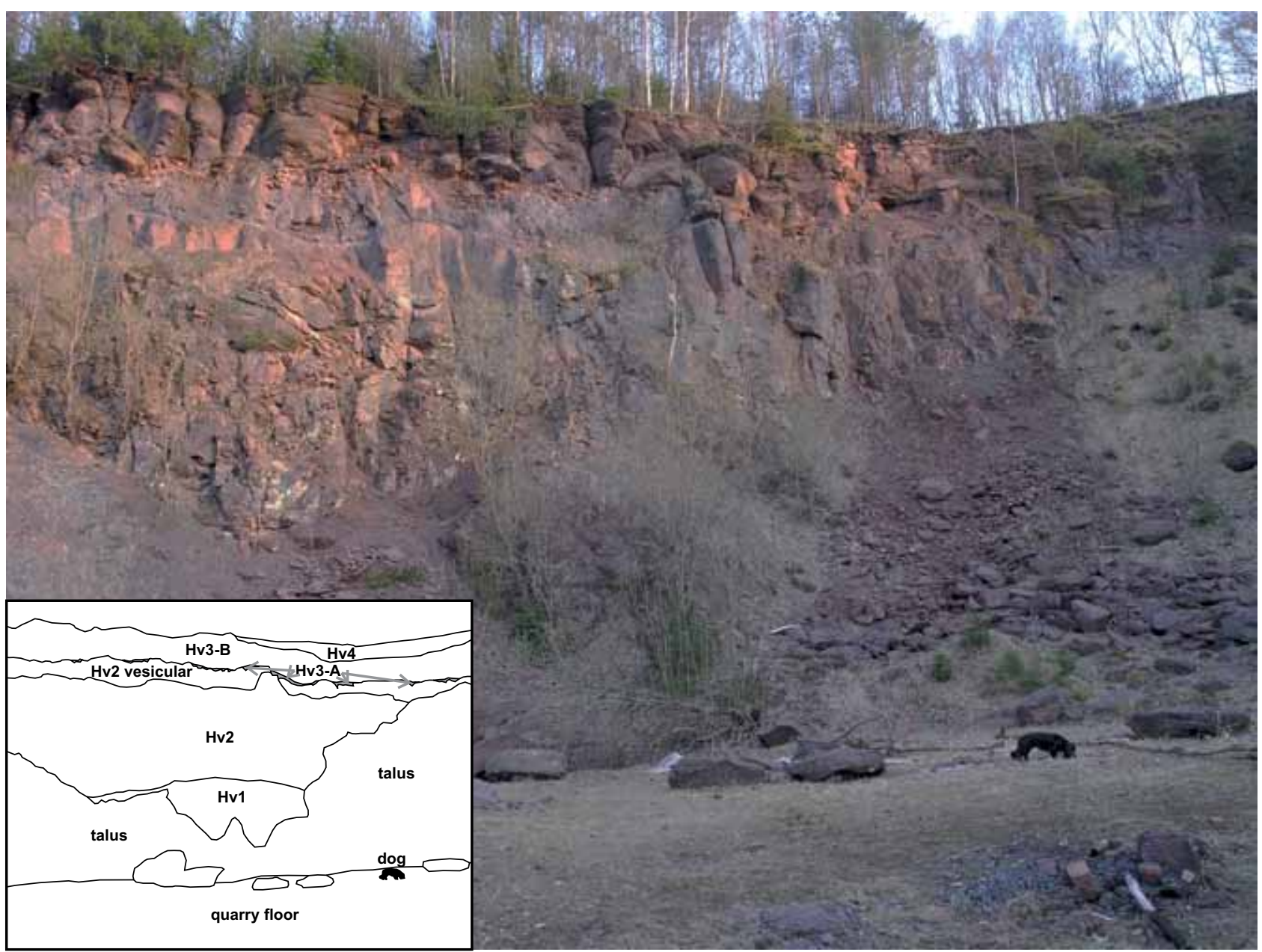

Fig. 4 Overview of the Hvězda quarry. The dog is $c .40 \mathrm{~cm}$ high.

ash particles are clustered into dark-brown rounded ash aggregates $0.04-0.2 \mathrm{~mm}$ in diameter. The ash aggregates are massive and the individual aggregates are in contact with each other (Fig. 6c). The deposit is therefore clastsupported. The aggregates often contain single large or several smaller angular grains of quartz and feldspar. The post-depositional alteration and oxidation disabled study of ash particles morphology. The deposit is cemented by carbonate, which also partly replaced plagioclase.

Hv1-D is a $50 \mathrm{~cm}$ thick planar-bedded scoriaceous lapilli-tuff with lenses of scoriaceous lapillistone. Scoria fragments are concentrated in lenses. The texture is clast- to matrix-supported. The upper part of the layer contains angular fragments of sedimentary rocks. The scoria fragments (10-30 vol. \%) are mostly carbonatized, usually reaching the size of $\sim 4 \mathrm{~mm}$ and occasionally up to $2 \mathrm{~cm}$. The deposit contains also clasts of mafic lava partly or completely replaced by calcium carbonate. The lava originally consisted of plagioclase and olivine as no relics after pyroxene were observed. Transition from massive glomeroporphyritic lava to scoria can be seen in some clasts. Both scoria and massive lava fragments occur in cores of armoured lapilli. The ash particles consist of devitrified cuspate glass shards (common pyroclasts fragmented by vesicle nucleation and growth during eruption), magmatic crystals (pseudomorphs after olivine and plagioclase) and fragments of quartz. The Hv1-D layer also contains accretionary lapilli (which are fairly common, ranging between 10 and 40 vol. \%) reaching up to 4 $\mathrm{mm}$ in diameter. The accretionary lapilli are classified as rim-type (sensu Schumacher and Schmincke 1991) with a single rim zone. Similarly to the HV-1C, we observed also ash aggregates in the Hv1-D. These are again massive in texture, without distinguishable core and rim and with variable grain size of ash particles.

Hv1-E is hematitized lithic-rich lapilli-tuff. No chloritized scoria fragments can be seen macroscopically in this layer, which is $c .40 \mathrm{~cm}$ thick. The deposit consists of fragments of mafic lava up to $1 \mathrm{~cm}$ across, lithics of siltstone, quartz grains, fragments of olivine and plagioclase crystals and brown hematitized ash. The ash builds up the groundmass and is also present in the rim of scarce armoured lapilli. 
Hvězda

quarry

grain size

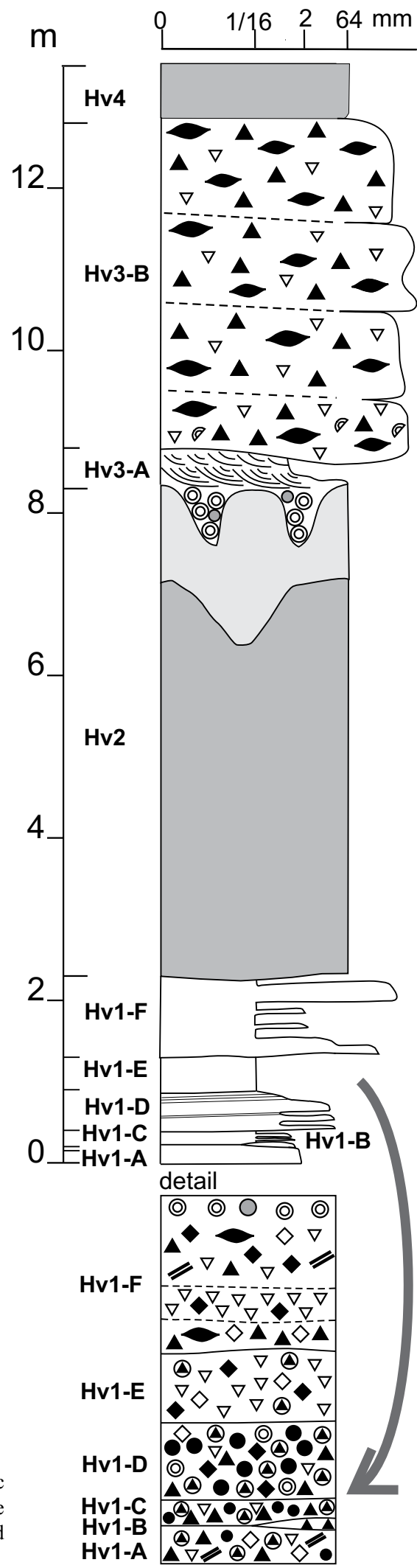

Hv1-B

Hv1-A

$\Delta \nabla \geqslant \theta \Delta \nabla$
K1

borehole

grain size

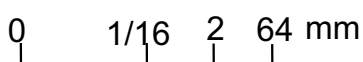

$\mathrm{m}$

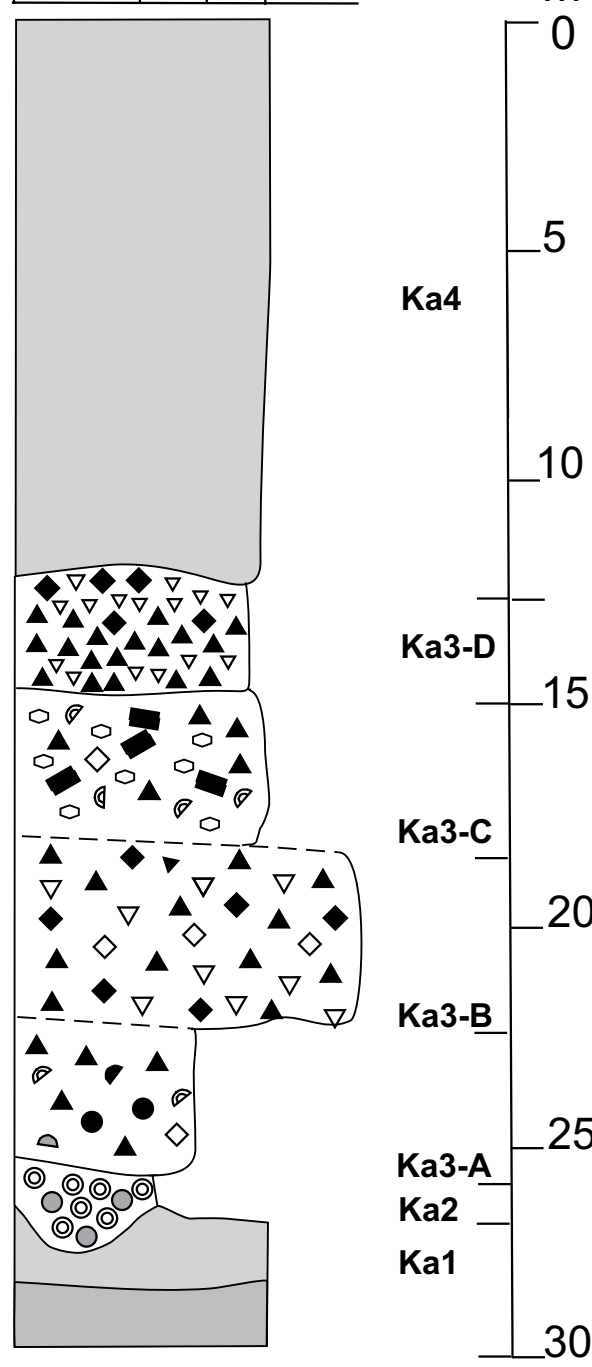

30

Fig. 5 Schematic lithostratigraphic columns of the rocks exposed in the Hvězda quarry and those encountered in the $\mathrm{K} 1$ borehole.

vesicle-rich brecciated lava coherent lava surge deposits

- spindle-shaped bomb

mica flakes

$\diamond \quad$ litics

$\checkmark \quad$ lava fragments

- scoria fragments

(4) armoured lapilli

- ash aggregates

O core-type AL

(2) rim-type AL

( ) (and their fragments)

$\nabla \quad$ glass shards 


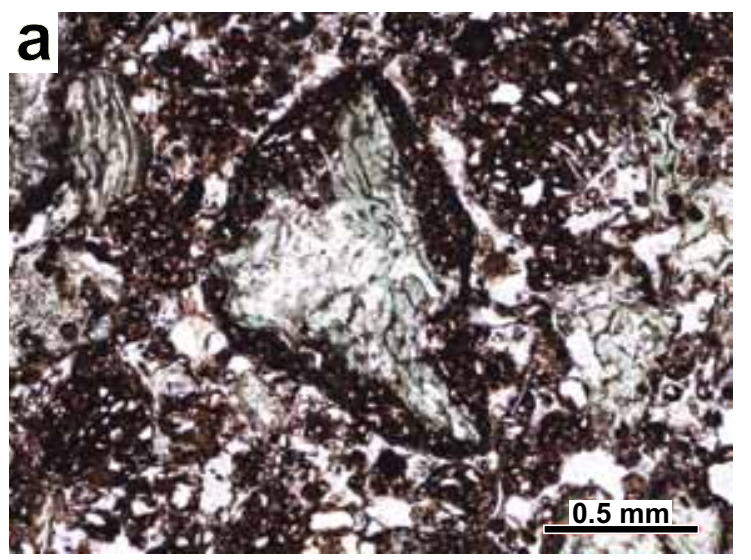

C $0.2 \mathrm{~mm}$ '8Y

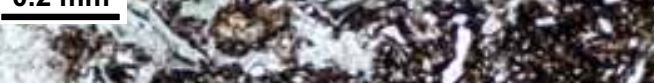

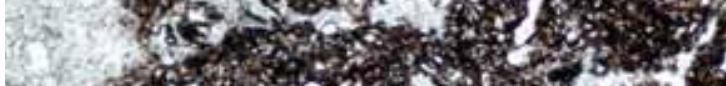

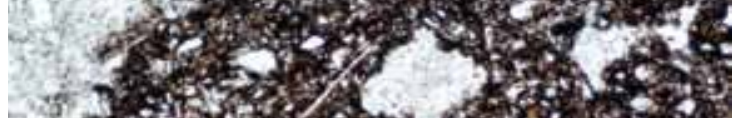

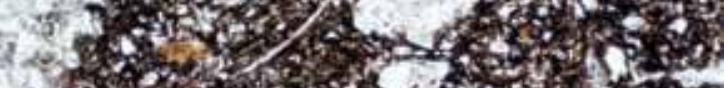

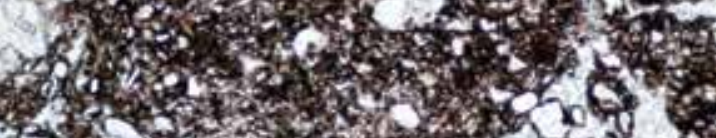
an

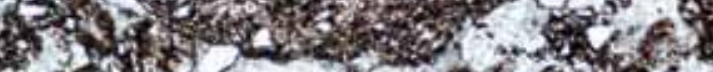
Solvo
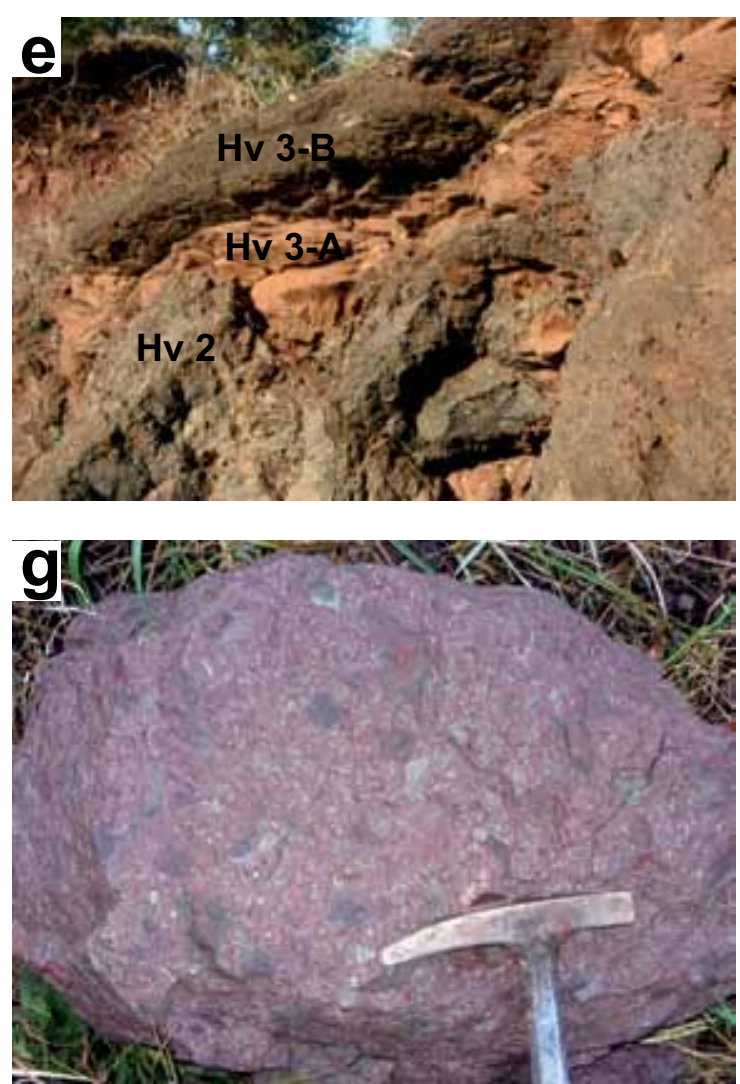
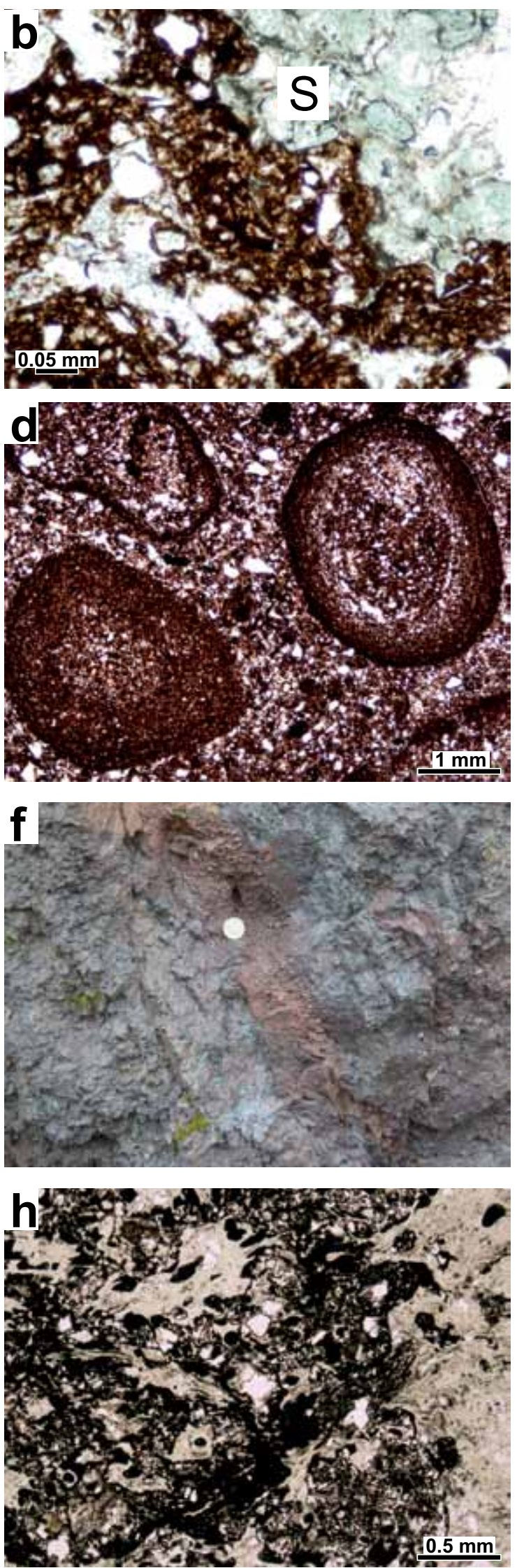
The grain size varies considerably in the layer Hv1-F with thickness of $100 \mathrm{~cm}$. Tuff-breccia with volcanic bombs up to $25 \mathrm{~cm}$ in diameter occurs in the lowermost and upper parts. In the rest, $5-20 \mathrm{~cm}$ thick beds of scoriaceous lapillistone alternate with up to $10 \mathrm{~cm}$ thick beds of hematitized vitroclastic tuff with abundant crystal fragments. The rounded to spindle-shaped volcanic bombs consist of finely vesicular mafic lava with olivine and plagioclase phenocrysts enclosed in a very fine groundmass. Corroded quartz xenocrysts occur occasionally. All beds are relatively well sorted with clastsupported texture. The lapillistone facies is dominated by fragments of chloritized scoria about $0.5-1 \mathrm{~cm}$ in size, with clast-supported fabric. The tuff beds consist of magmatic-crystal fragments (altered olivine and plagioclase), quartz grains and devitrified glass shards. The uppermost part is rich in accretionary lapilli (hereforth abbreviated as "AL"). In general, the rim-type dominate over core-type AL (Fig. 6d). The accretionary lapilli are up to $1 \mathrm{~cm}$ in diameter, some of them are complete and round but fragments occur also. The fragments are massive and could correspond to both cores of rim-type or core-type AL. The accretionary lapilli are enclosed in ash composed of devitrified glass shards and fragments of magmatic olivine and plagioclase as well as xenocrystic quartz grains.

The pyroclastic sequence Hv1 is overlain by lava Hv2. The lava is $c$. $6 \mathrm{~m}$ thick with a planar and sharp, nonbrecciated base, massive interior and nearly $3 \mathrm{~m}$ thick vesicle-rich brecciated upper part. Intense brecciation caused significantly stronger weathering compared to the massive facies. Central zone of the lava shows columnar jointing with metre-thick vertical columns. Lava includes olivine pseudomorphs (up to $3 \mathrm{~mm}$ ), small laths of plagioclase (up to $1 \mathrm{~mm}$ long), anhedral clinopyroxene and $\mathrm{Fe}-\mathrm{Ti}$ oxides. The strongly brecciated top of the lava features abundant pockets and open cracks extending down to $3 \mathrm{~m}$ into the massive lava.

The overlying succession Hv3 consists of two parts (Hv3-A and Hv3-B - Fig. 6e). Up to $2 \mathrm{~m}$ thick $\mathrm{Hv} 3-\mathrm{A}$ is represented by accretionary lapilli rich tuff

\footnotetext{
$\diamond$

Fig. 6 Volcanic rocks exposed in the Hvězda quarry. Macrophotos (e-g) and photomicrographs (PPL; a-d, h). a-Scoria fragment coated with accreted ash grains and surrounded with ash aggregates in matrix, layer Hv1-C; b - Detail of ash-coated scoria (S) fragment in Hv1-C; $\mathbf{c}$ - Massive ash aggregate in the groundmass of Hv1-C layer; $\mathbf{d}$ - Core- and rim-type accretionary lapilli in Hv1-F; e - Fine-grained phreatomagmatic pyroclastics (Hv3-A) levelling the brecciated top of lava, overlain by mafic pyroclastic flow deposits (Hv3-B), the part of outcrop shown is about $3 \mathrm{~m}$ high; $\mathbf{f}$ - Crack in brecciated top of lava filled with diagonally-bedded surge (bottom) and accretionary lapilli-rich fall deposits (top); $\mathbf{g}$ - Detail of scoriaceous mafic pyroclastic flow deposits of Hv3-B; $\mathbf{h}$ - Photomicrograph of scoriaceous mafic pyroclastic flow deposits Hv3-B, large scoria fragment (right) surrounded by groundmass of small scoria fragments and cuspate glass-shards.
}

and cross-bedded tuff. These fine-grained pyroclastic deposits filled the cracks, pockets and cavities in the autoclastic breccia of Hv2 lava (Rapprich 2008a, b). Fine-grained massive tuff with accretionary lapilli alternates with layers of tuff displaying cross bedding (Fig. 6f). These deposits vary from fine ash at the base, via AL randomly distributed in the ash to accretionary lapilli-supported texture on the top. The AL are of rimtype (Fig. 7). Fragments of feldspar and glass shards in the core reach up to $150 \mu \mathrm{m}$. The ash particles of the rim never exceed $40 \mu \mathrm{m}$ and usually vary about $10 \mu \mathrm{m}$ in diameter. Locally, AL-poor ash covers AL-rich horizon. The tuff consists of (devitrified) glass shards with scarce $(<5$ vol. $\%)$ phenocrysts of plagioclase (up to $0.5 \mathrm{~mm}$ ). Xenolithic material is represented by muscovite, quartz and $\mathrm{K}$-feldspar and its amount reaches up to 3 vol. \%. Upper part of the Hv3-A layer shows cross bedding. The upper contact with overlying tuff-breccia is mostly erosional. Locally, remnants of original surface of the Hv3-A were preserved beneath tuff-breccia Hv3-B. The surface is characterized by the presence of asymmetric impact structures, which are $2-3 \mathrm{~cm}$ deep and contain the impacting bullets in places. Here, large accretionary lapilli (up to $3 \mathrm{~cm}$ ) acquired a saucer shape upon impact.

Thickness of overlying scoriaceous tuff-breccia Hv3$\mathrm{B}$ reaches $4 \mathrm{~m}$. This unit includes up to five depositional units with no internal scouring contacts, $60-110 \mathrm{~cm}$ thick each. These deposits are crudely subhorizontally layered, have prevailing coarse matrix and abundant angular lithics (siltstones, up to $15 \mathrm{~cm}$ ), spindle-shaped bombs (up to $30 \mathrm{~cm}$ ) and fragments of altered scoria (20-40 vol. \%, up to $15 \mathrm{~cm}$ ). These coarse-grained pyroclastic deposits with slightly undulating base locally gathered fragments of accretionary lapilli. The texture is coarse-matrix supported with poor sorting (Fig. 6g). Larger vesicular fragments (lapilli to bombs) are enclosed in a matrix of cuspate glass shards (Fig. $6 \mathrm{~h}$ ). Crystals of plagioclase, olivine and pyroxene $0.2-3$ $\mathrm{mm}$ across are enclosed in pyroclasts. Glass shards without phenocrysts are also abundant. Mica, feldspar and quartz xenocrysts account for $0.5-2$ vol. $\%$ of the matrix and their size varies up to $1 \mathrm{~mm}$.

The sequence exposed in the Hvězda quarry is capped with another massive coherent mafic volcanic rock Hv4. This volcanic body has a sharp non-brecciated basal contact but its top is not exposed. The most prominent mineral in the aphanitic rock is plagioclase in laths c. $2 \mathrm{~mm}$ long. Olivine pseudomorphs are much smaller if compared to Hv2 lava, not exceeding $1 \mathrm{~mm}$. Anhedral clinopyroxene occurs scarcely. There are domains of devitrified glass among the plagioclase laths. As the upper part of the coherent body is not exposed, its emplacement setting (lava or sill) may not be assessed. 


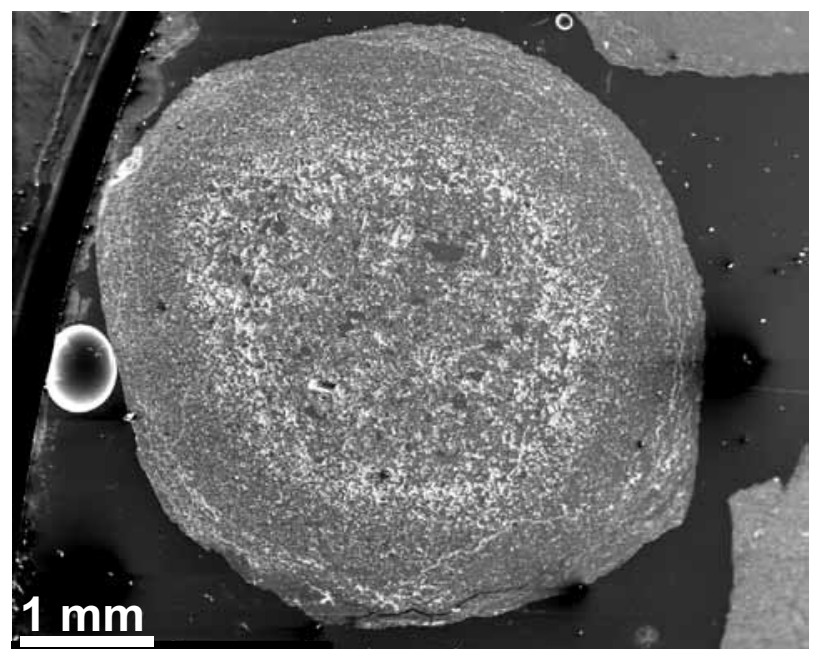

Fig. 7 Secondary electron image of an accretionary lapillus. The darker particles are fragments of plagioclase crystals. Unit Hv3-A in the Hvězda quarry.

\subsection{K1 borehole $\left(50^{\circ} 32^{\prime} 22^{\prime \prime} N, 15^{\circ} 29^{\prime} 07^{\prime \prime} E\right)$}

The K1 borehole was drilled in volcanic rocks of the Levín Volcanic Field (Fig. 2) in 2010. It was completely cored till the depth of $30 \mathrm{~m}$, where it was stopped. It did not reach the base of the volcanic sequence but four distinct lithologies were distinguished (Fig. 5).

Amygdaloidal mafic lava (K1-1) is the deepest rock unit sampled. The borehole penetrated this lava at the depth of 27-30 m, i.e. right to the bottom. This rock contains pseudomorphs after olivine up to $3 \mathrm{~mm}$ and glomerocrysts of olivine and plagioclase (both up to 2 $\mathrm{mm}$ individual crystals) enclosed in matrix of plagioclase, pseudomorphs after olivine and $\mathrm{Fe}-\mathrm{Ti}$ oxides.

The surface of the lava consists of autoclastic breccia, c. $1 \mathrm{~m}$ thick. The cracks and pockets in the lava breccia are filled with tuff rich in rim-type accretionary lapilli (K1-2). This deposit is identical to the Hv3-A layer exposed in the Hvězda quarry.

Poorly sorted volcaniclastic deposits overlie the tuff with accretionary lapilli. These deposits are documented at the depths between 12.5 and $26 \mathrm{~m}$. The texture of this deposit is heterogeneous with four principal layers (K13A, B, C, D).

The lowermost scoriaceous lapilli-tuff K1-3A is matrix-supported with abundant clasts (up to 40 vol. \%) of chloritized and/or carbonatized scoria up to $5 \mathrm{~mm}$ in diameter. Scoria, often coated with hematite, predominates among the clasts over round massive ash aggregates reaching $3 \mathrm{~mm}$ in size (ash aggregate up to core-type $\mathrm{AL}$ ). Fragments of rim-type AL, siltstones and quartz grains occur as well. Generally, the grain-size contrast between clasts and matrix is low as the grain-size of matrix varies between $c .0 .1$ and $0.5 \mathrm{~mm}$. The matrix consists mainly of cuspate shards. Fragments of magmatic plagioclase, quartz grains, lithics and mica flakes (mostly muscovite) are also present (up to 10 vol. \%).

The scoriaceous tuff-breccia K1-3B is poorly sorted and matrix-supported. The grain-size contrast between clasts and matrix is significantly higher compared to K1-3A. The clasts reach several centimetres in diameter and consist of chloritized and/or carbonatized scoria (Fig. 8), fragments of mafic lava and pieces of siltstones. Deformed core-type and fragments of rim-type AL were also observed. The matrix is similar to the lower unit in both grain size and composition including frequent cuspate shards. Quartz grains derived from underlying Upper Carboniferous to Lower Permian sandstones and conglomerates are also frequent.

The scoriaceous lapillistone $\mathrm{K} 1-3 \mathrm{C}$ is characterized by much smaller volume and size of scoria fragments, usually not exceeding $1 \mathrm{~cm}$ in diameter. This deposit is very rich in mica flakes (mainly muscovite) and quartz grains. The latter are present in both clasts and matrix, locally accounting for up to $50 \%$ of the rock volume. This facies contains also abundant fragments of rim-type AL.

The well-sorted and clast-supported lapillistone alternating with tuff K1-3D was drilled at the depth of 15-12.5 m. The lapillistone consists of scoria and vesiculated lava clasts, the tuff layers are dominated by devitrified cuspate shards.

The sequence exposed by the drilling is crowned with coherent massive mafic, slightly porphyritic rock (K1-4). Its base at $12.5 \mathrm{~m}$ is straight and sharp and its upper part (9-0 $\mathrm{m}$ of drilling) is strongly weathered, passing continuously to weathering products towards the surface. The rock consists of abundant idiomorphic plagioclase laths not exceeding $2 \mathrm{~mm}$ in length. Small pseudomorphs after olivine c. $0.2 \mathrm{~mm}$ across are also frequent. The clinopyroxene is xenomorphic, filling up the spaces in between phenocrysts. There are also mi-

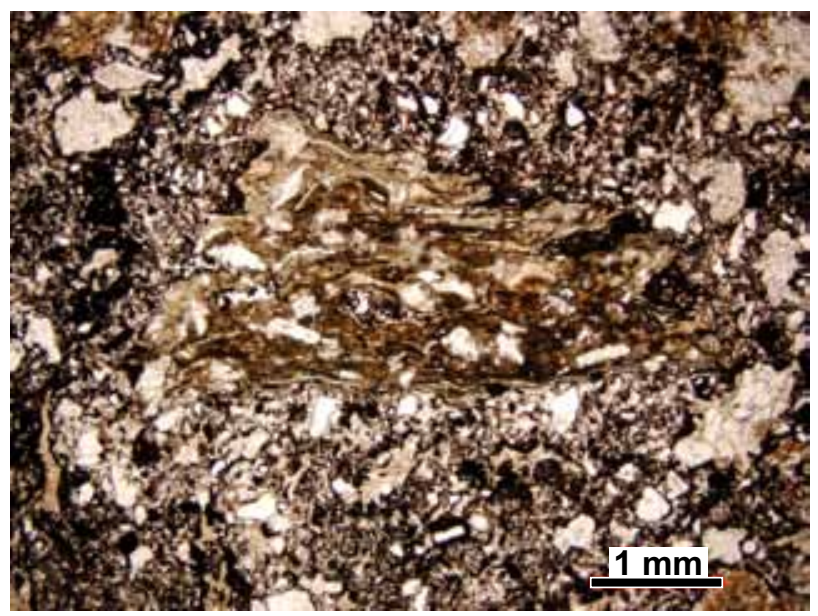

Fig. 8 Fragment of altered densely vesiculated glass (piece of scoria) enclosed in matrix of cuspate shards; unit K13-B at the depth of 20.05 $\mathrm{m}$ in the $\mathrm{K}-1$ borehole. 
crocrystalline domains present in the rock, most likely representing result of devitrification of the volcanic glass. The apical part of this volcanic body is not exposed and thus, similarly to the Hv4 rock, its emplacement setting remains unconstrained.

\subsection{Jíva Hill $\left(50^{\circ} 32^{\prime} 05^{\prime \prime} N, 15^{\circ} 27^{\prime} 56^{\prime \prime} E\right)$}

A set of small randomly distributed outcrops can be found on slopes of the Jíva Hill (west of the Hvězda quarry, Fig. 2). Basaltic lava Jv2 (it is not clear whether equivalent to Hv2 or Hv4) separates underlying lapilli-tuff Jv1 from lapillistone to tuff-breccia Jv3 up the hill.
Lapilli-tuff Jv1 is matrix-supported and poorly sorted. Clasts of slightly altered scoria, vesiculated and coherent lava (all $0.5-2 \mathrm{~cm}$ ) are enclosed in matrix of devitrified cuspate glass-shards, crystal fragments, quartz grains and scarce mica flakes. Generally these deposits resemble pyroclastic deposits Hv3-B in the Hvězda quarry.

Lapillistone to tuff-breccia Jv3 above the lava flow is horizontally to subhorizontally bedded. The beds show normal grading and are well sorted and clast-supported. The deposit consists of chloritized scoria fragments, glass shards (both together up to 40 vol. \%), quartz grains (up to 40 vol. \%), mica flakes and magmatic crystals, usually coated with chloritized glass. The glass shards are well
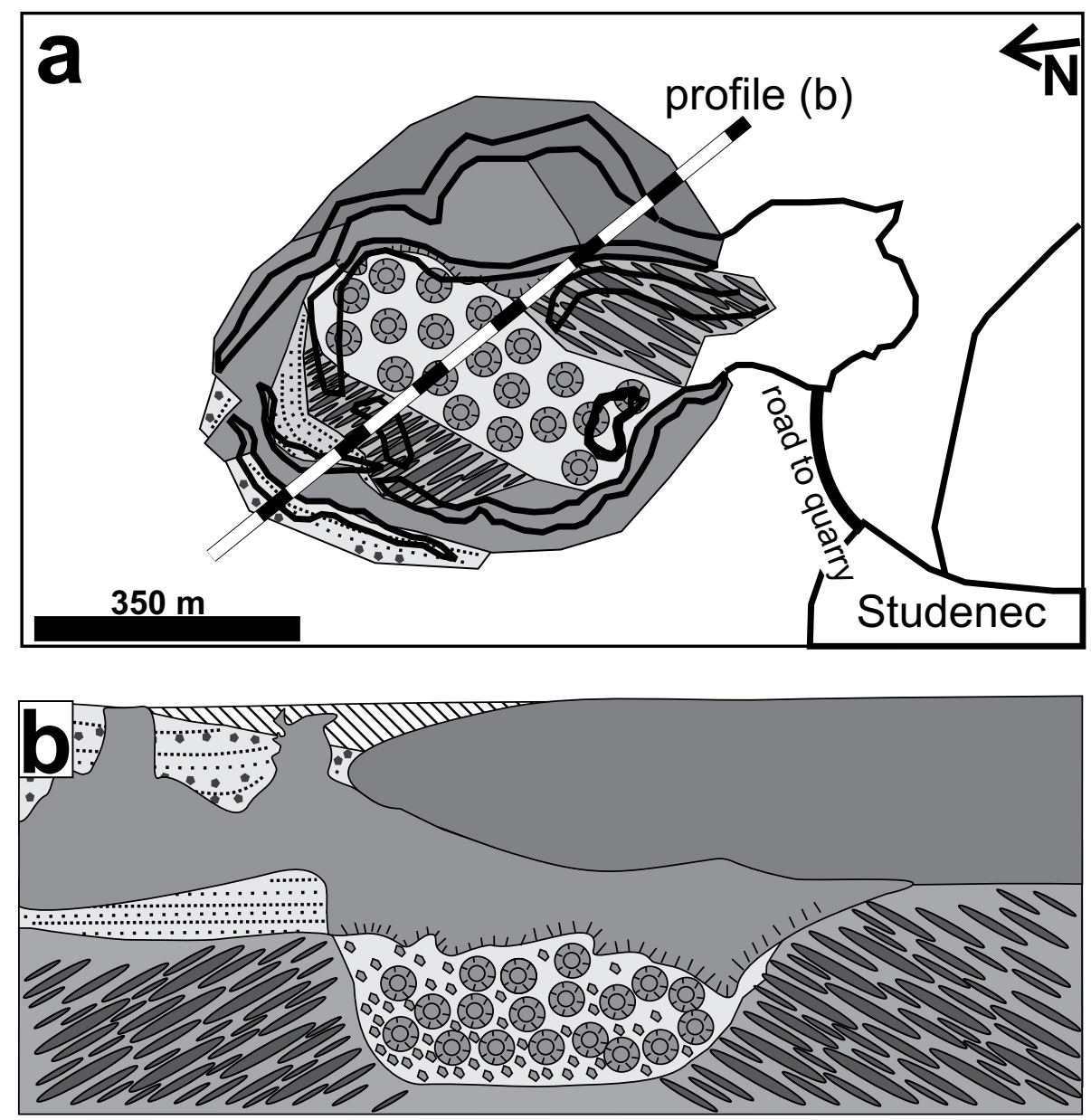

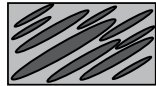

St1 - agglutinate

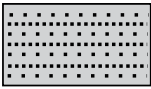

Fig. 9 Geological situation in the Studenec quarry. a - Sketch map of the lithologies exposed; b - Schematic profile across the quarry - length of the section is approximately $800 \mathrm{~m}$, its height is c. $20 \mathrm{~m}$

St4 - massive lava

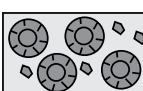

St2 - lapillistone and tuff

$\because \because \because: \cdots$

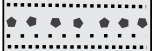

St5 - tuff-breccia to lapillistone

St3 - pillow lava and hyaloclastites

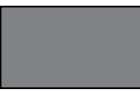

St6 - mafic volcanic rock (lava/sill)

Rotliegend (Autunian) continental sediments 
outlined by bubble walls, some contain relics of plagioclase phenocrysts or glomerocrysts. Ash aggregates up to $2 \mathrm{~mm}$ in diameter with variable grain size were also observed.

\subsection{Studenec quarry $\left(50^{\circ} 33^{\prime} 21^{\prime \prime} N\right.$, $15^{\circ} 33^{\prime} 28^{\prime \prime} \mathrm{E}$ )}

Different facies of mafic volcanic rocks were found in the Studenec quarry (Fig. 9). Agglutinates St1 (Fig. 10a-b) are exposed in places at the base of the quarry. The agglutinates consist of welded, weakly vesicular lava shreds forming a spatter deposit. The flattened lava shreds are up to $70 \mathrm{~cm}$ long and steeply inclined to the $\mathrm{S}$ near the quarry entrance and to NW on the northern wall. Variable degree of oxidation produces colour variation of the spatter. Fresher cores are grey or violet whereas the rims of the shreds tend to reddish tones. Borders between individual shreds are obscured in the more oxidized domains. Thickness of these volcaniclastic deposits reaches $5 \mathrm{~m}$ but the base is not exposed. The lava shreds consist of plagioclase phenocrysts and glomerocrysts enclosed in groundmass of altered glass. The pseudomorphs after olivine occur scarcely, quartz xenocrysts are more frequent. In some shreds, the vesicles are flattened due to welding but mostly they have round or irregular shapes. Vesicles are small and they do not tend to coalescence as it is commonly observed in scoria of Strombolian type eruptions (Polacci et al. 2006). As the central part of the quarry has been already exploited, correlation between individual outcrops of the agglutinates remains unclear. Both occurrences may represent separated remnants of a single cone/rampart or two coexisting cones.

Subhorizontally bedded lapillistone and tuff St2 is exposed in the northern part of the quarry, overlying the accumulations of agglutinates St1. The total thickness of these pyroclastic deposits reaches $4 \mathrm{~m}$. Individual beds, 1 to $25 \mathrm{~cm}$ thick, show normal or, more rarely, reverse grain-size grading. The deposits are moderately sorted and clast-supported. The lowermost layer about $10 \mathrm{~cm}$ thick consists of well-sorted lapillistone with angular clasts of mafic lava about $1 \mathrm{~cm}$ in diameter. Higher in the sequence, lapillistone beds with thickness up to $15 \mathrm{~cm}$ alternate with coarse-tuff beds. Some of the layers display low-angle cross bedding. The bases of coarse-grained tuff layers are undulated. At the base of the unit discussed are present occasional outsized clasts of basaltic lava (up to $15 \mathrm{~cm}$ ) in coarse-grained layers. The lava clasts show usually macroscopically distinguishable light-coloured rims. Outsized clasts in the upper part are associated with impact sag structures (Fig. 10c). The geometry of the clasts can be seen under the microscope (Fig. 11). Angular to subrounded fragments of hypocrystalline and vesicular olivine basalt to olivine-free basalt (or basaltic andesite) prevail with up to 45 vol. \%. Apart of these hydroclasts, highly vesicular scoria occurs in these deposits. Scoria fragments have irregular shape outlined by bubble walls, whereas the fragments of slightly vesiculated hypocrystalline olivine basalt have straight or irregular outlines with no signs of vesicle-driven fragmentation. The olivine basalt consists of plagioclase laths and pseudomorphs after olivine (about $0.5 \mathrm{~mm}$ ) enclosed in altered glass. Angular to subangular quartz grains, fragments of volcanic crystals and lithics of volcanic and sedimentary rocks are also present. Some layers are cemented by carbonate.

Pillow lavas and associated hyaloclastites St3 are exposed near the agglutinates St1. They can be seen in the central and northern parts of the quarry. Transverse and longitudinal cross sections of pillow lava are exposed. The length of pillows varies from $1 \mathrm{~m}$ to lobes of several meters, whereas their diameter does not exceed $1 \mathrm{~m}$. Some pillows have typical radial joints (Fig. 10d) and concentric arrangement of vesicles. The rims of individual pillows (Fig. 10e) and larger hyaloclasts consist of green argillized glass. Glassy rims may reach a few centimetres in thickness. Hyaloclastite breccia surrounds pillows especially in the lowermost part of the outcrop. It consists of roughly isometric subangular fragments several centimetres in diameter (Fig 10f). Interclast space is mostly filled with secondary minerals like calcite, zeolite, chlorite and agate. Upwards, the amount of pillows increases, whereas the volume of hyaloclastite or pillow breccia decreases.

The pillow lava passes upwards to massive coherent facies St4. Base of the lava is straight and lacks any signs of brecciation where pyroclastics St2 are present underneath. On the other hand, the morphology of its upper contact is very irregular with numerous vertical "apophyses" rising up to $4 \mathrm{~m}$ above the rest of the lava. Near the top of this coherent body, a piece of lava with ropy structure surface was found in the talus (Fig. 10g).

The volcanic sequence exposed in the Studenec quarry is crowned with tuff-breccia to lapillistone of reddish brown colour (St5). Total thickness reaches $4.5 \mathrm{~m}$ to the west and decreases to the east. These volcaniclastics are subhorizontally bedded (each bed up to $30 \mathrm{~cm}$ thick) with normal or reverse grading of successive beds. The deposits are poorly sorted, matrix- to clast-supported (Fig. 10h)

Fig. 10 Volcanic rocks exposed in the Studenec quarry. a, b - Blocks of agglutinate St1 composed of stretched and flattened welded shreds of basaltic lava. Variation in colour reflects different degrees of oxidation in cores and rims of individual shreds; $\mathbf{c}$ - Pyroclastic surge and fall deposits St2 with impact sag structure beneath larger ballistic clast; $\mathbf{d}$ - Pillow lava St3, each pillow is about $1 \mathrm{~m}$ in diameter; $\mathbf{e}$ - Lava pillow surrounded with hyaloclastite breccia St3; f - Detail of hyaloclastite breccia St3; $\mathbf{g}$ - Ropy surface of lava (the coin is $25 \mathrm{~mm}$ in diameter); $\mathbf{h}$ - Coarse-grained pyroclastic deposits St5 rich in bombs. 

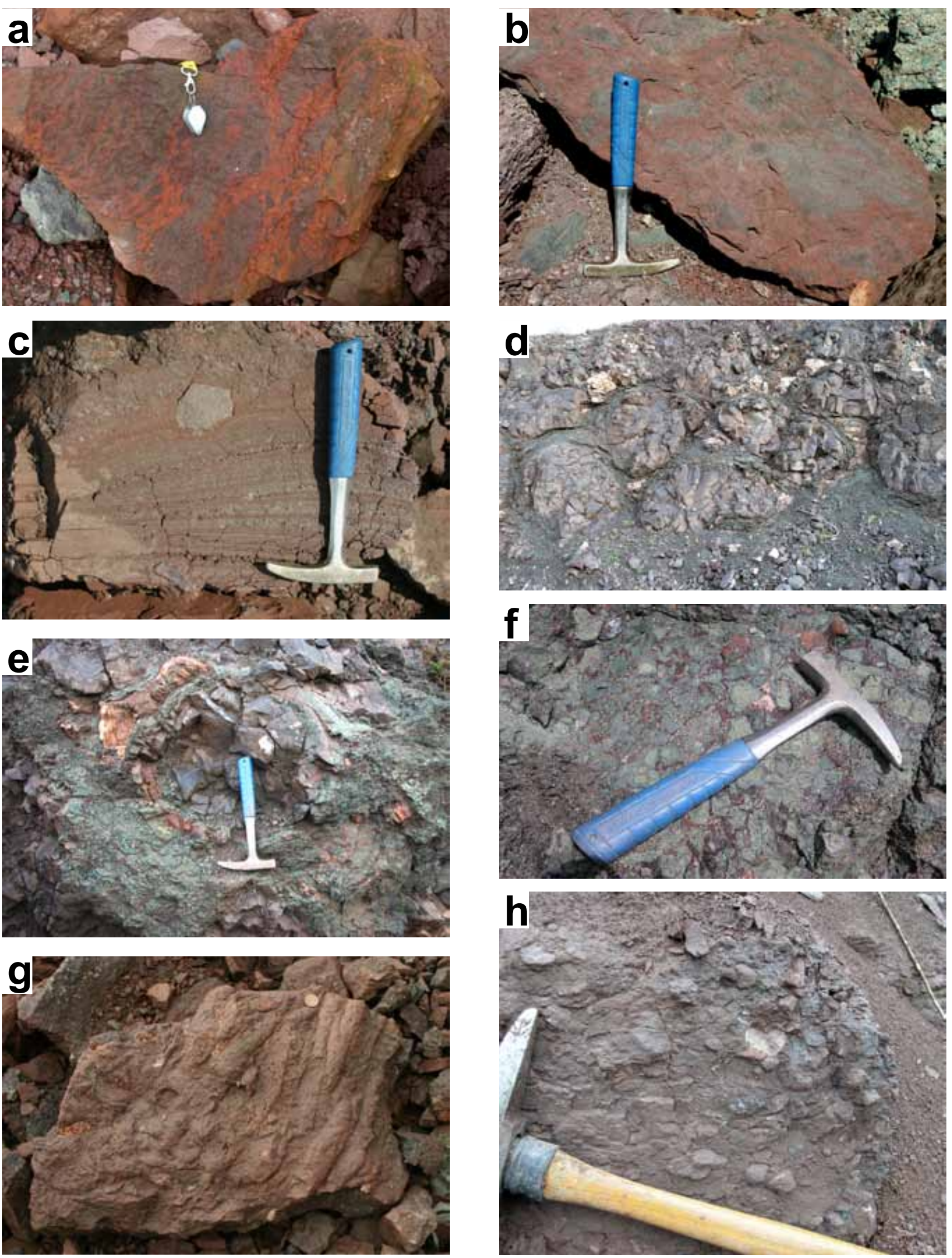


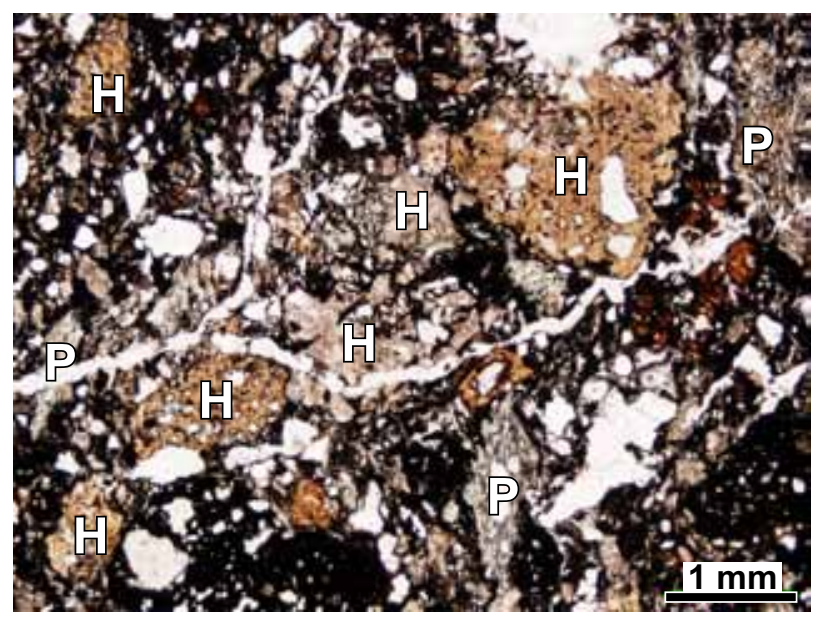

Fig. 11 Photomicrograph (PPL) of phreatomagmatic pyroclastic deposits with altered pyroclastic ( $\mathrm{P}-$ scoria, greyish to greenish tones) and hydroclastic ( $\mathrm{H}$ - pale-brown and brown) glass shards in hematitized matrix (black).

and consist mostly of fragments of mafic lava and altered carbonatized glass. Occasionally, spindle-shaped bombs up to $30 \mathrm{~cm}$ in diameter were found. Thin sections of the matrix show composition and texture similar to the lapillistone St2 - fragments of hypocrystalline basalt, scoria, and abundant grains of quartz. The volcaniclastic deposits do not fill the spaces between the apophyses on the lava surface completely. Prosečné Fm. sediments, which buried the entire volcanic field and its products, level the irregular morphology. Lava St4 is covered with another body of coherent aphanitic mafic volcanic rock St6 in the easternmost part of the quarry where tuff-breccia St5 misses. Similarly to Hv4, its emplacement cannot be interpreted, as the upper part of the body is not exposed.

\section{Discussion}

In all sites we could observe variations in effects of water on eruptive behaviour. Several eruptive phases were documented in the Hvězda quarry. Clast-supported layers dominate the sequence Hv1. The deposits combine scoria fragments, frequently in cores of armoured lapilli, with accretionary lapilli. Armoured lapilli form during eruption within a steam envelope above the vent due to magma-water interaction at high gas content of the magma (e.g., Martin et al. 2004). The accretionary and armoured lapilli in the Hv1 sequence affirm the phreatomagmatic character of the eruption. Scoria fragments inside of the armoured lapilli cores provide evidence for incomplete magma-water interaction. Therefore, the Hv1 unit should be interpreted as a deposit of a phreato-Strombolian eruption. The clast-supported fabric argues for fall-out or surge deposition. As the cross-bedding was not observed in these deposits, surge deposition is not likely to explain this sequence. On the other hand, poor sorting could be interpreted in terms of fall-out deposition near the source vent. High amounts of ash aggregates were determined in beds Hv1-A-D. The ash aggregates are similar to coretype accretionary lapilli in structure. The deposits with ash aggregate-supported fabric resemble surge deposits of Upper Laacher See Tephra (Schumacher and Schmincke 1991), where accretion of aggregates continued to exceed $2 \mathrm{~mm}$ resulting in core-type accretionary lapilli.

Hv3-A is the bed richest in accretionary lapilli among all documented deposits. Rim-type AL of concentric accretionary texture prevails but core-type AL also occur. Such products are typical of violent phreatomagmatic eruptions (e.g., Rolandi et al. 2004). Cross-bedded tuffs in the upper part of the Hv3-A were deposited from surge produced also by a phreatomagmatic eruption. Overlying Hv3-B unit is relatively coarse-grained and contains bombs and outsized lithics. Many of the volcanic bombs are spindle-shaped. The shape of these bombs and high amount of moderately vesicular scoria correspond to Strombolian-type eruption (e.g., Rosi et al. 2006). Clastsupported fabric may have originated in proximal fall-out deposits on cone or in deposits of mass flows. Proximal deposition of Strombolian fall on the cone would produce bedding inclined at $c .30^{\circ}$ but the unit Hv3-B is bedded subhorizontally. On the other hand, there is no evidence for a pronounced palaeotopography, which is a prerequisite for the formation of lahars. Additional argument against sedimentation of these deposits from debris flow is absence of well rounded scoria fragments. Mafic pyroclastic flows (scoria flows) seem to be a better candidate to explain the depositional mechanism of these rocks. Mafic pyroclastic flows may originate from the collapse of Strombolian eruptive column (Sparks et al. 1978) or from the collapse of a lava dome (Cole et al. 2002). The latter ones are very rich in poorly or non-vesiculated lava fragments and do not fit to deposits observed in the Hvězda quarry. Height of the eruption column may have substituted for the absent topography necessary for the gravity driven flow. The mafic pyroclastic flows are not as common as silicic ones but they were documented in many areas (El Salvador: Rapprich and Hradecký 2005; Argentina: Berlotto et al. 2006; Japan: Miyabuchi et al. 2006; Sicily: Behncke et al. 2008). Deformed and broken $\mathrm{AL}$ occur also in the Hv3-B beds, interpreted as mafic pyroclastic flow deposits. As the base of the pyroclastic flows is erosional, we suppose the $\mathrm{AL}$ were captured into the flows from underlying phreatomagmatic pyroclastic deposits.

The deposits drilled in the $\mathrm{K} 1$ borehole resemble those documented in the central part of the Hvězda quarry. Correlation is possible also due to the short distance (1.2 $\mathrm{km}$ ) between the two localities. Support for phreatomagmatic eruption-related origin is provided by rim-type 
AL-dominated deposit within the cracks and pockets of the lava breccia in the drill-core, identical to the Hv3-A unit in the Hvězda quarry. The phreatomagmatic eruption was succeeded by Strombolian eruptions producing scoria-rich lapilli-tuffs to tuff-breccias.

Steeply inclined agglutinates St1 in the Studenec quarry consist of large welded lava shreds. Flattening of the shreds suggests splash deformation of large molten lava shreds typical of Hawaiian-type explosive volcanic activity (Summer et al. 2005). These deposits should be therefore interpreted as a remnant of a spatter cone or a spatter rampart. The angular fragments of hypocrystalline basaltic lava in overlying lapillistones St2 should be interpreted in terms of magma quenching caused by magma-water interaction. Cross bedding of some tuff and lapillistone layers documents surge deposition. Some pyroclasts were transported ballistically, as shown by the presence of impact sag structures. Combination of all observed features suggests near-vent facies of a phreatomagmatic eruption.

The pyroclastic deposits St2 are overlain with coherent massive lava St4. This lava passes laterally into pillow lava and hyaloclastite breccia filling up the space between occurrences of agglutinates St1. Pillow-lava texture accompanied with pillow fragment breccia and hyaloclastite breccia are produced during subaquatic effusions (e.g., Tucker and Scott 2009). Preserved morphology of the spatter cone roughly corresponds to level of boundary between subaquatic (St3) and massive facies (St4) of the lava. Transition from Hawaiian eruption St1 to phreatomagmatic eruption $\mathrm{St} 2$ as well as temporal relation of subaquatic lava facies postdating agglutinates suggests a possible significant influence of volcanism on landscape evolution and water retaining. Monogenetic cone damming a stream and creating a lake is represented e.g. by Puy du Tararet damming the Lake of Chambon in French Massif Central (Nowell 2006). The influence of lavadammed lake on eruptive style and transition from Strombolian to phreatomagmatic eruption was described e.g. by Weinstein (2007). Because of seasonality of Permian climate (Schneider et al. 2006), the valley dammed with a spatter cone could be relatively soon filled with water, so the next lava flow would be emplaced in a shallow temporary lake. Alternatively, the lake could have created in the crater of spatter cone. Subsequent phreatomagmatic activity would deepen the crater and preserve remnants of the spatter buried under phreatomagmatic deposits. "Apophyses" observed on top of the lava St4 could mimic apophyses of high-level intrusions. On the other hand, blocky lavas have very irregular surface with jags reaching several meters. The scoriaceous tuff-breccia St5 is characterized in similar way as Hv3-B deposits according to grain size, sorting, fabric and clast petrography. Hence, model of deposition from mafic pyroclastic flows (derived from collapse of a Strombolian eruption column) is assumed also for this unit.

\section{Conclusions}

The deposits of various eruptive styles of the Levín Volcanic Field confirmed existence of Permian monogenetic volcanic activity within the Krkonoše Piedmont Basin. The mafic lavas and shallow-level intrusions ("melaphyres") in the central part of the Basin were accompanied by explosive activity of variable styles:

- The eruptions of Strombolian style were producing mafic pyroclastic flows.

- The activity recorded in the Hvězda quarry includes phreato-Strombolian, phreatomagmatic and Strombolian eruptions alternating with lava effusions.

- Ash aggregates observed in some layers in the Hvězda quarry are considered to have originated by accretion in ash plumes.

- Agglutinates documented in the Studenec quarry were produced by Hawaiian-style eruptive activity.

- Significant role for volcanism on evolution of the landscape and eruption environment has been documented in the Studenec quarry. Volcanic activity contributed in formation of a lake, which modified the style and facies of subsequent volcanic activity.

Acknowledgements. The volcanological study of the Levín Volcanic Field was carried out within the framework of geological mapping of the Bohemian Paradise Geopark financially supported by the Czech Ministry of Environment through the project $\mathrm{VaV}-\mathrm{SP} / 2 \mathrm{e} 6 / 97 / 08$. The Czech-German cooperation in research on Late Paleozoic volcanic systems runs within the frame of the VENTS project (Volcanic Systems Within the Central European Permo-Carboniferous Intermontane Basins and Their Basement - http://www.ing.uni.wroc.pl/ VENTS/). Assistance by Khaled El Gameel during fieldwork and logistic support by Tomáš Řídkošil from the Regional Museum in Turnov are highly acknowledged. The manuscript benefited from constructive comments by J. Lexa, an anonymous reviewer and handling editor V. Kachlík.

\section{References}

Awdankiewicz M (1999) Volcanism in a late Variscan intramontane trough: the petrology and geochemistry of the Carboniferous and Permian volcanic rocks of the Intra-Sudetic Basin, SW Poland. Geol Sudetica 32: 83-111

AwdANKIEwicz M (2004) Sedimentation, volcanism and subvolcanic intrusions in a late Palaeozoic intramon- 
tane trough (the Intra-Sudetic Basin, SW Poland). In: Breitkreuz C, Petford N (eds) Physical Geology of High-Level Magmatic Systems. Geological Society of London Special Publications 234: 5-11

AwDANKIEWICZ M (2005) Reconstructing an eroded scoria cone: the Miocene Sośnica Hill volcano (Lower Silesia, SW Poland). Geol Quart 49: 439-448

Bednarz U, Schmincke H-U (1990) Evolution of the Quaternary melilite-nephelinite Herchenberg volcano (East Eifel). Bull Volcanol 52: 426-444

Behncke B, Calvari S, Giammanco S, Neri M, Pinkerton H (2008) Pyroclastic density currents resulting from the interaction of basaltic magma with hydrothermally altered rock: an example from the 2006 summit eruptions of Mount Etna, Italy. Bull Volcanol 70: 1249-1268

Benda V, Bíža J, Bouda A, Franke M, Hájek O, Knobloch E, Návratová K, StŘeda J, Štajgl R, Unzeitig M, Valterová P, Vlasák J, Žáková B (1981) Syřenov, hard coal, searching phase of survey. Unpublished report, Czech Geological Survey - Geofond, Prague, pp 1-180 (in Czech)

Benek R, Kramer W, McCann T, Scheck M, Negendank JFW, Korich D, Huebscher H-D, Bayer U (1996) Permo-Carboniferous magmatism of the NE German Basin. Tectonophysics 266: 379-404

Bertotto GW, Bjerg EA, Cingolani CA (2006) Hawaiian and Strombolian style monogenetic volcanism in the extra-Andean domain of central-west Argentina. J Volcanol Geotherm Res 158: 430-444

Bíža J, Franke M, Knobloch E, Středa J, Unzeitig M, VAlterová P, Vlasák J, Ž́́ková B (1982) Syřenov, hard coal, complement to final report. Unpublished report, Czech Geological Survey - Geofond, Prague, pp 1-28 (in Czech)

Breitkreuz C, Mock A (2004) Are laccolith complexes characteristic of transtensional basin systems? Examples from Permocarboniferous Central Europe. In: BREITKREuZ C, Petford N (eds) Physical Geology of High-Level Magmatic Systems. Geological Society of London Special Publications 234: 13-32

Breitkreuz C, Ehling B-C, Sergeev S (2009) Chronological evolution of an intrusive/extrusive system: the Late Paleozoic Halle Volcanic Complex in the north-eastern Saale Basin (Germany). Z Dtsch Gesell Geowiss 160: 173-190

Brookfield ME (1980) Permian intermontane basin sedimentation in southern Scotland. Sediment Geol 27: 167-194

Burbank DW, Johnson GD (1983) The late Cenozoic chronologic and stratigraphic development of the Kashmir intermontane basin, Northwestern Himalaya. Palaeogeogr Palaeoclimatol Palaeoecol 43: 205-235

Carrasco-NúŇEz G, Ort MH, Romero O (2007) Evolution and hydrological conditions of a maar volcano (Atexcac
Crater, eastern Mexico). J Volcanol Geotherm Res 159: 179-197

Cole PD, Calder ES, Sparks RSJ, Clarke RA, Druit TH, Young SR, Herd RA, Harford CL, Norton GE (2002) Deposits from dome-collapse and fountain-collapse pyroclastic flows at Soufriére Hills Volcano Montserrat. In: DruitT TH, KoKelaAr BP (eds) The Eruption of Soufriére Hills Volcano, Montserrat (1995 to 1999). Geological Society London Memoirs 21: 231-262

Geissler M, Breitkreuz C, Kiersnowski H (2008) Late Paleozoic volcanism in the central part of the Southern Permian Basin (NE Germany, W. Poland): facies distribution and volcano-topographic hiati. Int J Earth Sci 97: 973-989

Genareau K, Valentine GA, Moore G, Hervig RL (2010) Mechanisms for transition in eruptive style at a monogenetic scoria cone revealed by microtextural analyses (Lathrop Wells volcano, Nevada, U.S.A.). Bull Volcanol 72: 593-607

HEAD JW III, WiLson L (1989) Basaltic pyroclastic eruptions: influence of gas release patterns and volume fluxes on fountain structure, and the formation of cinder cones, spatter cones, rootless flows, lava ponds and lava flows. J Volcanol Geotherm Res 37: 261-271

HošEK M, KŘiž L, PelunĚK V (1963) Trutnov - Náchod, survey for building stone, phase I: prospecting. Unpublished report, Czech Geological Survey - Geofond, Prague, pp 1-43 (in Czech)

Hoth K, Huebscher H-D, Korich D, Gabriel W, Enderlein F (1993) Die Lithostratigraphie der permokarbonischen Effusiva im Zentralabschnitt der Mitteleuropäischen Senke - Der permokarbone Vulkanismus im Zentralabschnitt der Mitteleuropäischen Senke, Teil I. Geol Jb Reihe A 131: 179-196

Houghton BF, Schmincke H-U (1989) Rothenberg scoria cone, East Eifel: a complex Strombolian and phreatomagmatic volcano. Bull Volcanol 52: 28-48.

Keating GN, Valentine GA, Krier DJ, Perry FV (2007) Shallow plumbing system for small-volume basaltic volcanoes. Bull Volcanol 70: 563-582

Kereszturi G, Németh K, Csillag G, Balogh K, Kovács $J$ (2011) The role of external environmental factors in changing eruption styles of monogenetic volcanoes in a Mio/Pleistocene continental volcanic field in western Hungary. J Volcanol Geotherm Res 201: 227-240

KONEČNÝ V, LEXA J (2003) Evolution of the phreatomagmatic/extrusive/intrusive complex of the Bulhary maar-diatreme volcano in southern Slovakia. Geolines 15: 47-51

Krawczyk CM, Stiller M, DEKORP-Basin Research Group (1999) Reflection seismic constraints on Paleozoic crustal structure and Moho beneath the NE German Basin. Tectonophysics 314: 241-253

LORENZ V (2003) Maar-diatreme volcanoes, their formation, and their setting in hard rock or soft rock environments. Geolines 15: 72-83 
LORENZ V, HANeKe J (2004) Relationship between diatremes, dykes, sills, laccoliths, intrusive-extrusive domes, lava flows, and tephra deposits with unconsolidated watersaturated sediments in the late Variscan intermontane Saar-Nahe Basin, SW Germany. In: Breitkreuz C, Petford N (eds) Physical Geology of High-Level Magmatic Systems. Geological Society of London Special Publications 234: 75-124

LORENZ V, KURSZLAUKIS S (2007) Root zone processes in the phreatomagmatic pipe emplacement model and consequences for the evolution of maar-diatreme volcanoes. J Volcanol Geotherm Res 159: 4-32

Martin U, Németh K (2006) Eruptive mechanism of phreatomagmatic volcanoes from the Pinacate volcanic Field: comparison between Crater Elegante and Cerro Colorado, Mexico. Z Dtsch Gesell Geowiss 157: 451-466

Martin U, Breitkreuz C, Egenhoff S, Enos P, Jansa L (2004) Shallow-marine phreatomagmatic eruptions through a semi-solidified carbonate platform (ODP leg 144, Site 878, Early Cretaceous, MIT Guyot, West Pacific). Mar Geol 204: 251-272

Martínek K, Štolfová K (2009) Provenance study of Permian non-marine sandstones and conglomerates of the Krkonoše Piedmont Basin (Czech Republic): exotic marine limestone pebbles, heavy minerals and garnet composition. Bull Geosci 84: 555-568

Martínek K, Blecha M, DaněK V, Francư J, Hladíková J, JohnovÁ R, UliČNÝ D (2006) Record of palaeoenvironmental changes in a Lower Permian organic-rich lacustrine succession: integrated sedimentological and geochemical study of the Rudník Member, Krkonoše Piedmont Basin, Czech Republic. Palaeogeogr Palaeoclimatol Palaeoecol 230: 85-128

Miyabuchi Y, Watanabe K, Egawaet Y (2006) Bomb-rich basaltic pyroclastic flow deposit from Nakadake, Aso Volcano, southwestern Japan. J Volcanol Geotherm Res 155: 90-103

Mock A, Ehling BC, Breutkreuz C (2005) Anatomy of a laccolith complex - geometry and texture of porphyritic rhyolites in the Permocarboniferous Halle Volcanic Complex (Germany). Neu Jb Geol Paläont, Abh 237: 211-271

Nowell D (2006) The Chaine des Puys volcanoes of the Auvergne, France. Geology Today 24: 231-238

Paulick H, Breitrkeuz C (2005) The Late Paleozoic felsic lava-dominated large igneous province in North East Germany: volcanic facies analysis based on drill cores. Int J Earth Sci 94: 834-850

PešEK J (ed) (2001) Geology and Deposits of Upper Palaeozoic Limnic Basins of the Czech Republic. Czech Geological Survey, Prague, pp 1-243 (in Czech)

Polacci M, Corsaro RA, Andronico D (2006) Coupled textural and compositional characterization of basaltic sco- ria: insights into the transition from Strombolian to fire fountain activity at Mount Etna. Geology 34: 201-204

PoniKelská B (1982) Melaphyres of the Levín highland. Unpublished MSci. thesis, Charles University, Prague, pp 1-88 (in Czech)

Prouza V, TÁsler R (2001) Krkonoše Piedmont Basin. In: PEŠEK J (ed) Geology and Deposits of Upper Paleozoic Limnic Basins of the Czech Republic. Czech Geological Survey, Prague, pp 128-166 (in Czech)

RAPPRICH V (2008a) Accretionary lapilli in melaphyres of the Krkonoše Piedmont Basin. Zpr geol výzk za r 2007, 39-41 (in Czech)

RAPPRICH V (2008b) Deposits of phreatomagmatic activity in the Levín Volcanic Complex, Krkonoše Piedmont Basin. In: Breitkreuz C, Hoffmann U, Renno AD, Stanek K (eds) Abstract Volume and Field Guide on the Late Paleozoic Magmatic Evolution of Saxony, May 15-18, 2008. Wissenschaftliche Mitteilungen, TU Bergakademie Freiberg, pp 15

Rapprich V, Hradecký P (2005) The Cinotepeque Range of central El Salvador: geology, magma origin, and volcanism. Bull Geosci 80: 277-286

Rapprich V, Cajz V, KošŤák M, Pécskay Z, Řídkošil T, RAŠKA P, RADOŇ M (2007) Reconstruction of eroded monogenic Strombolian cones of Miocene age: a case study on character of volcanic activity of the Jičín Volcanic Field (NE Bohemia) and subsequent erosional rates estimation. J Geosci 52: 169-180

Risso C, Németh K, Combina AM, Nullo F, Drosina M (2008) The role of phreatomagmatism in a Plio-Pleistocene high-density scoria cone field: Llancanelo Volcanic Field (Mendoza), Argentina. J Volcanol Geotherm Res 169: $61-86$

Rolandi G, Munno R, Postiglione I (2004) The A.D. 472 eruption of the Somma volcano. J Volcanol Geotherm Res 129: 291-319

RoMer R, Förster H-J, BreItKreuz C (2001) Intracontinental extensional magmatism with a subduction fingerprint: the late Carboniferous Halle Volcanic Complex (Germany). Contrib Mineral Petrol 141: 201-221

Rosi M, Bertagnini A, Harris AJl, Pioli L, Pistolesi M, RIPEPE M (2006) A case history of paroxysmal explosion at Stromboli: timing and dynamic of the April 5, 2003 event. Earth Planet Sci Lett 243: 594-606

SCHÄFER A (1989) Variscan molasse in the Saar-Nahe basin (W-Germany), Upper Carboniferous and Lower Permian. Geol Rundsch 78: 499-524

Schneider WJ, Korner F, Roscher M, Kroner U (2006) Permian climate development in the northern peri-Tethys area - the Lodéve Basin, French Massif Central, compared in a European and global context. Palaeogeogr Palaeoclimatol Palaeoecol 240: 161-183

Schovánková D (1985) Petrochemical types and chemical trends of Late-Paleozoic volcanism in Bohemian Massif. 
Unpublished report, Czech Geological Survey, Prague, pp 1- 43 (in Czech)

Schovánková D (1989) Petrology of Late-Paleozoic volcanic rocks of the Krkonoše Piedmont Basin. Part I. Permian basaltic andesites. Unpublished report, Czech Geological Survey, Prague, pp 1- 49 (in Czech)

Schumacher R, Schmincke H-U (1991) Internal structure and occurrence of accretionary lapilli - a case study at Laacher See Volcano. Bull Volcanol 53: 612-634

Scolamacchia T, Macías JL, Sheridan MF, Hughes SR (2005) Morphology of ash aggregates from wet pyroclastic surges of the 1982 eruption of El Chichón Volcano, México. Bull Volcanol 68: 171-200

SeGHEDI I (2011) Permian rhyolitic volcanism, changing from subaqueous to subaerial in post-Variscan intracontinental Sirinia Basin (SW Romania-Eastern Europe). J Volcanol Geotherm Res 201: 312-324

Sigurdsson H (ed) (1999) Encyclopedia of Volcanoes. Academic Press, New York, pp 1-1416

SкоŘEPA J (1978) Permo-Carboniferous in Krkonoše piedmont - report on water resources. Unpublished report, Czech Geological Survey - Geofond, Prague, pp 1-150 (in Czech)

Sparks RSJ, Wilson L, Hulme G (1978) Theoretical modeling of the generation, movement and emplacement of pyroclastic flows by column collapse. J Geophys Res 83(B4): 1727-1739

StÁrková M, ČÁp P, HoláseK O, TASÁryová Z, Rapprich V, Нrосн T (2010) Basic geological map of the Czech Republic, scale 1:25 000, sheet Lomnice nad Popelkou 03-431. Unpublished manuscript, Czech Geological Survey, Prague

Stollhofen H, Stanistreet IG (2007) Interaction between bimodal volcanism, fluvial sedimentation and basin development in the Permo-Carboniferous Saar-Nahe Basin (south-west Germany). Basin Res 6: 245-267

Stollhofen H, Fromherz B, Stanistreet IG (1999) Volcanic rocks as discriminants in evaluating tectonic versus climatic control on depositional sequences, PermoCarboniferous continental Saar-Nahe Basin. J Geol Soc, London 156: 801-808
Summer JM, Blake S, Matela RJ, Wolf JA (2005) Spatter. J Volcanol Geotherm Res 142: 49-65

ŠreinovÁ B, Šrein V (1997) Melaphyres of the Levín table land. Bull mineral-petrolog Odd Nár Muz (Praha) 4-5: 200-203 (in Czech)

Timmerman MJ (2008) Paleozoic magmatism. In: McCann T (ed) The Geology of Central Europe - Vol 1. Precambrian and Palaeozoic. Geological Society, London, pp 665-748

Tucker D, Scott KM (2009) Structures and facies associated with flow of subaerial basaltic lava into a deep freshwater lake: the Sulphur Creek lava flow, North Cascades, Washington. J Volcanol Geotherm Res 185: 311-322

Ulrych J, Štěránková J, Novák JK, Pivec E, Prouza V (2002) Volcanic activity in Late Variscan Krkonoše Piedmont Basin: petrological and geochemical constraints. Slovak Geol Mag 8: 219-234

Ulrych J, Pešek J, Štěránková-Svobodová J, Bosák P, Lloyd FE, von Seckendorff V, Lang M, Novák JK (2006) Permo-Carboniferous volcanism in late Variscan continental basins of the Bohemian Massif (Czech Republic): geochemical characteristic. Chem Erde 66: 37-56

Valentine GA, Krier D, Perry FV, Heiken G (2005) Scoria cone construction mechanisms, Lathrop Wells volcano, southern Nevada, USA. Geology 33: 629-632

Valentine GA, Perry FV, Krier D, Keating GN, Kelley RE, Cogbill AH (2006) Small-volume basaltic volcanoes: eruptive products and processes, and posteruptive geomorphic evolution in Crater Flat (Pleistocene), southern Nevada. Geol Soc Am Bull 118: 1313-1330

van Wees JD, Stephenson RA, Ziegler PA, Bayer U, Mc Cann T, Dadler R, Gaupp R, Narkiewicz M, Bitzer F, SCHECK M (2000) On the origin of the Southern Permian Basin, Central Europe. Mar Pet Geol 17: 43-59

Weinstein Y (2007) A transition from Strombolian to phreatomagmatic activity induced by a lava flow damming water in a valley. J Volcanol Geotherm Res 159: 267-284

ZiEgLer PA (1990) Geological Atlas of Western and Central Europe. Shell International Petroleum, Mij. BV, Geological Society Publishing House, Bath, pp 1-239 